\title{
THE DISTRIBUTION OF TRANSFERRIN GENES IN CATTLE
}

\author{
ALAN JAMIESON \\ A.R.C. Animal Breeding Research Organisation, Edinburgh, 9 *
}

Received 28.vii.65

\section{INTRODUCTION}

WHEN animal blood sera are subjected to electrophoresis in gelled starch, the proteins in various serum fractions are distinguished by their relative electrophoretic mobilities, and some fractions show genetic variants.

The cattle transferrin polymorphs are controlled by a series of at least eight co-dominant genes at the Tf locus (Jamieson, 1965). The cattle transferrin genes show much genetic diversity within herds and wide differences between breeds. The transferrin variants have never been deliberately selected and presumably the responsible genes have survived domestication, breed formation and many forms of artificial selection. The transferrin genes may assist in tracing the genetic structure of breeding populations and indicate the genetic affinities of the breeds and the earlier geographic varieties.

This paper presents summaries of the occurrence of transferrin types, and the frequencies of transferrin genes in most of the breeds of cattle found in Britain, and in a number of separate herds within these breeds.

The proportions of transferrin types are discussed in relation to the breeding structure of the material and an attempt is made to relate their frequencies in different breeds with their geographic origins. Finally, evidence from other sources has been collected and compared with the data in this paper.

\section{MATERIAL, METHODS AND NOTATION}

\section{(i) Origin of Material}

The numbers, varieties and sources of the serum samples representing the breeds of cattle tested are indicated in table $\mathrm{I}$. The table shows separate totals for bulls and for other cattle. The grand total of 2862 tested cattle were represented by I 830 fresh serum samples and 1032 serum samples from cold storage. The cattle were born in 1120 herds.

Blood samples were collected from $147 \mathrm{I}$ bulls at 28 artificial insemination centres throughout Great Britain from 1957 to 1963 and from 8 bulls on farms. The stored sera from 808 bulls were used earlier in tests recognising six transferrin types (Ashton 1958, Ogden 1963). Most of the remaining $67 \mathrm{r}$ bulls, which provided fresh sera, were more recent arrivals at the bull centres. Where duplicate samples occurred, bulls already represented as stored samples were tested and confirmed but not reported among the fresh sample totals.

Most of the tested bulls were born in breeders' herds. Many of the tested cows were born in commercial herds and subsequently collected into experimental herds.

* Present address : Ministry of Agriculture, Fisheries and Food, Fisheries Laboratory, Lowestoft, Suffolk. 
Some of the purebred and most of the crossbred cows were born within one experimental herd of this Organisation. Samples were obtained from cows in private herds to represent some of the breeds which were numerically small.

Cattle breeds have remained in genetic isolation for many generations. Within breeds, the breeding units are not well defined because some named herds are recognisable genetic units, whereas other named herds, mainly those using A.I., are really husbandry units within larger breeding units. In different breeds, herds showing all degrees of genetic isolation were distributed unevenly. This was often

TABLE I

The numbers of cattle tested for transferrin types were classed according to their breeds and the numbers of sub-populations in which they were born

\begin{tabular}{|c|c|c|c|c|c|c|c|c|}
\hline & & & \multicolumn{3}{|c|}{ Bulls } & \multicolumn{3}{|c|}{ Cows and others } \\
\hline \multicolumn{3}{|c|}{ Breed } & $\begin{array}{c}\text { Fresh } \\
\text { samples }\end{array}$ & $\begin{array}{l}\text { Stored } \\
\text { samples }\end{array}$ & $\begin{array}{c}\text { Herd } \\
\text { sources }\end{array}$ & $\begin{array}{c}\text { Fresh } \\
\text { samples }\end{array}$ & $\begin{array}{c}\text { Stored } \\
\text { samples }\end{array}$ & $\begin{array}{c}\text { Herd } \\
\text { sources }\end{array}$ \\
\hline Aberdeen Ang & & . & 53 & $5^{2}$ & 63 & 0 & 0 & 0 \\
\hline Ayrshire & . & $\dot{.}$ & $8 \mathrm{I}$ & I 24 & 87 & 296 & 145 & I 28 \\
\hline Beef Shorthorn & . & . & 0 & 0 & 0 & 0 & 39 & 3 \\
\hline Belted Gallowa & & . & 2 & 0 & I & 26 & 0 & I \\
\hline Blue Albion & . & . & o & 0 & 0 & I & o & I \\
\hline British Friesian & . & . & I 53 & 26I & I 79 & r 36 & 0 & 57 \\
\hline British White & . & . & I & 0 & I & 24 & 0 & I \\
\hline Charollais . & . & . & 23 & o & 23 & 0 & 0 & 0 \\
\hline Dairy Shortho & & . & 56 & $14 \mathrm{I}$ & 107 & o & 0 & $\mathbf{o}$ \\
\hline Devon $\quad$. & - & . & 21 & 24 & 30 & o & 0 & 0 \\
\hline Dexter : & . & . & $\mathbf{o}$ & o & 0 & 2 & 0 & I \\
\hline Dutch Friesian & . & . & 5 & o & 5 & $\mathbf{o}$ & o & $\mathbf{o}$ \\
\hline Galloway . & . & . & 5 & 4 & 8 & 0 & 40 & I \\
\hline Guernsey . & . & . & 50 & 62 & 67 & 37 & 0 & I \\
\hline Hereford . & . & . & I I I & 77 & I $5^{8}$ & 0 & 0 & 0 \\
\hline Highland . & $\cdot$ & . & 2 & o & I & I. 3 & $\mathbf{0}$ & I \\
\hline Jersey & - & . & 39 & 49 & 54 & 57 & 0 & I 6 \\
\hline Lincoln Red & $\cdot$ & $\cdot$ & 8 & 0 & 4 & o & $\mathbf{o}$ & o \\
\hline Longhorn . & . & . & 3 & o & 2 & 36 & $\mathbf{o}$ & 2 \\
\hline Northern Dair & Shortl & horn & 5 & o & 5 & o & o & 0 \\
\hline Red Dane . & . & . & 6 & 0 & 6 & 0 & $\mathbf{o}$ & 0 \\
\hline Red Poll . & . & . & I 7 & 0 & I I & I 7 & 0 & I \\
\hline South Devon & . & . & 2 & 14 & 9 & I 7 & 0 & I \\
\hline Sussex ; & - & . & 9 & o & 7 & o & $\mathbf{o}$ & 0 \\
\hline Welsh Black & $\cdot$ & . & 19 & 0 & 12 & 0 & 0 & o \\
\hline Miscellaneous & rosses & $\cdot$ & o & o & 0 & 534 & $\mathbf{o}$ & 66 \\
\hline \multirow{2}{*}{\multicolumn{3}{|c|}{ Totals }} & 671 & 808 & \multirow{2}{*}{840} & I I 59 & 224 & \multirow{2}{*}{$28 \mathrm{I}$} \\
\hline & & & \multicolumn{2}{|c|}{1479} & & \multicolumn{2}{|c|}{ I $3^{8} 3$} & \\
\hline
\end{tabular}

subject to the availability of animals in the breeds. For example, the rare British White breed was represented by 25 cattle in one herd, and the $4^{14}$ Friesian bulls were unevenly distributed over 179 herd sources. The largest herd sample was 54 bulls born in one herd, but the numbers of A.I. bulls of all breeds born in different herds showed an average ratio of 2.5 bulls per herd source, because most of the tested cattle represented single herd sources.

\section{(ii) Technique}

The electrophoretic technique used to separate the transferrins in cattle sera has been described in detail in another paper (Jamieson, 1965). 
(iii) Notation

The series of co-dominant genes at the cattle Tf locus, $\operatorname{Tf}^{a 1}, \mathrm{Tf}^{a 2}, \mathrm{Tf}^{b}, \mathrm{Tf}^{d 1}, \mathrm{Tf}^{d 2}$, $\mathrm{Tf}^{f}$, $\mathrm{Tf}^{e}$ and $\mathrm{Tf}^{\circ}$ in order of decreasing electrophoretic mobility, are shown in fig. 1 . Of these, $\mathrm{Tf}^{a}{ }^{a}, \mathrm{Tf}^{d 1}, \mathrm{Tf}^{d 2}$ and $\mathrm{Tf}^{e}$ are known in British cattle. The symbol $\mathrm{Tf}^{d}$ indicates unspecified proportions of $\mathrm{Tf}^{d 1}$ and $\mathrm{Tf}^{d \mathbf{2}}$ when quoting the results obtained by others before these two allelomorphs were differentiated.

The symbols for the four patterns of bovine transferrin bands found in Britain, Tf- $a 2$, Tf- $d_{1}$, Tf- $d_{2}$ and Tf- $e$ indicate the phenotypes appropriate to the four homozygous genotypes $\mathrm{Tf}^{a 2} / \mathrm{Tf}^{a}{ }^{2}, \mathrm{Tf}^{d 1} / \mathrm{Tf}^{d 1}, \mathrm{Tf}^{d 2} / \mathrm{Tf}^{d 2}$ and $\mathrm{Tf}^{e} / \mathrm{Tf}^{e}$. Similarly the six phenotypes Tf-a2dI, Tf-a2d2, Tf-a2e, Tf- $d_{1} d_{2}, \mathrm{Tf}-d_{1} e$, Tf- $d_{2} e$ have the heterozygous genotypes $\mathrm{Tf}^{a} / \mathrm{Tf}^{d 1}, \mathrm{Tf}^{a 2} / \mathrm{Tf}^{d 2}, \mathrm{Tf}^{a 2} / \mathrm{Tf}^{e}, \mathrm{Tf}^{d 1} / \mathrm{Tf}^{d 2}$, $\mathrm{Tf}^{d 1} / \mathrm{Tf}^{e}$ and $\mathrm{Tf}^{d 2} / \mathrm{Tf}^{e}$ (Jamieson, I965).

8 basic patterns appropriate to the 8 known cattle If genes

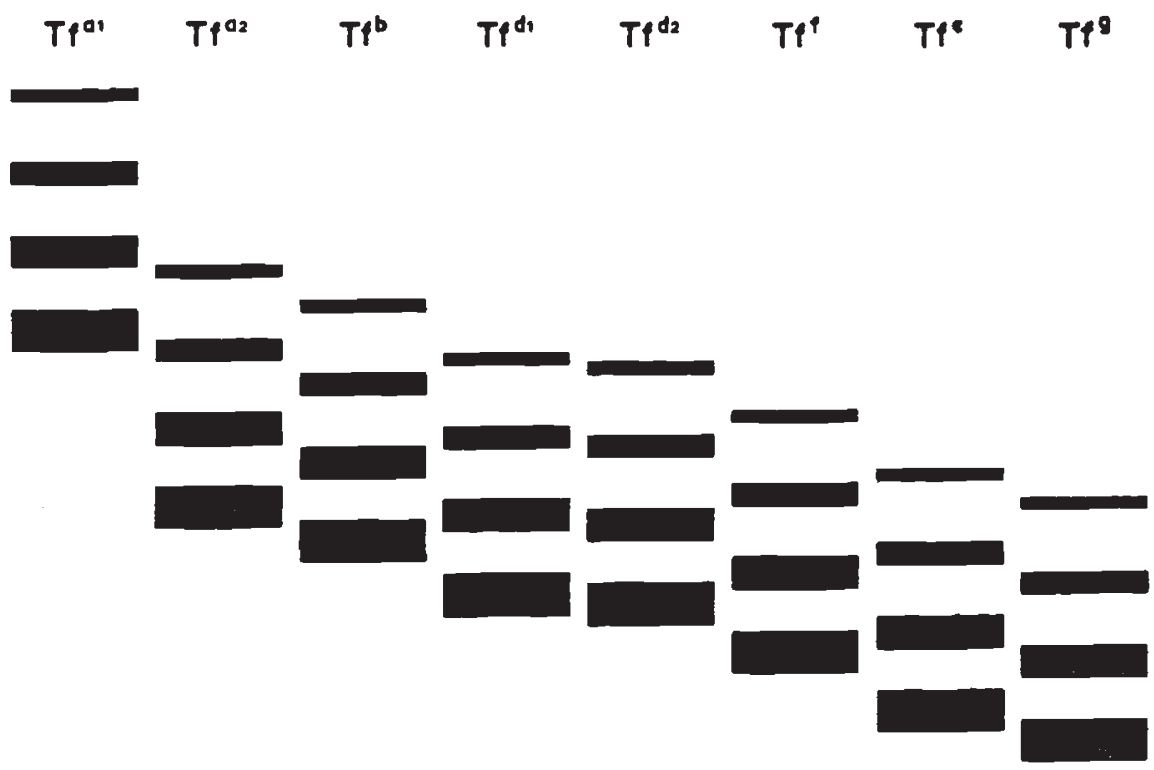

FIG. 1,-Distinct patterns of iron-binding proteins exist in the beta-globulin region of cattle sera. The eight illustrated patterns form the bases of all known bovine transferrin types as seen in homozygous cattle only. The twenty-eight heterozygotes, not shown, contain the same basic patterns superimposed in pairs.

\section{RESULTS}

The cattle transferrin data were interpreted genetically. The types and genes were identified and described numerically. The data were tested statistically for genetic equilibrium and for gene frequency differences.

\section{(i) Genetic equilibrium}

Equilibrium is expected among genes in isolated random-mating populations not disturbed by selection, mutation or genetic drift. The breeds were regarded as genetic populations largely isolated since their formation. The herds dispersed within the breed hierarchies were 
TABLE

Comparisons of the observed and expected numbers of transferrin types in samples

\begin{tabular}{|c|c|c|c|c|c|c|}
\hline \multirow{2}{*}{\multicolumn{3}{|c|}{ Cattle }} & \multicolumn{4}{|c|}{ Transferrin } \\
\hline & & & \multicolumn{4}{|c|}{ Homozygotes } \\
\hline \multicolumn{2}{|c|}{ Breed } & Source & Tf-a2 & $T f-d_{I}$ & $\mathrm{Tf}-\mathrm{d}_{2}$ & Tf-e \\
\hline Aberdeen A & ngus & 63 herds & $52 \quad(50)$ & $9 \quad(3)$ & $2 \quad(2)$ & I (I) \\
\hline Ayrshire & . & herd A & $5 \quad(4)$ & I (I) & $4 \quad(3)$ & (o) \\
\hline Ayrshire & • & 86 herds & I3 (12) & I 7 (II) & $33(28)$ & (2) \\
\hline Ayrshire & . & $\overline{87}$ herds & I 8 (I 5) & I8 (1 2) & $37(3 I)$ & (2) \\
\hline Ayrshire & . & twins. & $25 \quad(27)$ & I6 (II) & $40 \quad(36)$ & $4 \quad(3)$ \\
\hline Ayrshire & . & 28 herds & 22 (I 6$)$ & $3 \quad(6)$ & $28 \quad(22)$ & (I) \\
\hline Ayrshire & . & experiment . & $7 \quad(4)$ & $2 \quad(2)$ & $2 I \quad(2 I)$ & (I) \\
\hline Ayrshire & $\cdot$ & I6I herds. & 54 (47) & $2 \mathrm{I} \quad(19)$ & $89 \quad(78)$ & (5) \\
\hline \multicolumn{2}{|c|}{ Beef Shorthorn } & 3 herds & I4（I5） & $3 \quad$ (I) & $0 \quad(2)$ & (o) \\
\hline \multicolumn{2}{|c|}{ Belted Galloway } & I herd & $8 \quad(6)$ & I $\quad(0)$ & $4 \quad(4)$ & o $\quad(0)$ \\
\hline \multirow{2}{*}{\multicolumn{2}{|c|}{$\begin{array}{l}\text { British Friesian } \\
\text { British Friesian }\end{array}$}} & herd A & Io (9) & $4 \quad(3)$ & $9 \quad(7)$ & ... \\
\hline & & herd B & $4 \quad(4)$ & o (o) & $\ldots$ & o (I) \\
\hline \multicolumn{2}{|c|}{ British Friesian } & herd C & (I) & I $\quad(0)$ & I $\quad(2)$ & $0 \quad$ (I) \\
\hline \multirow{2}{*}{\multicolumn{2}{|c|}{$\begin{array}{l}\text { British Friesian } \\
\text { British Friesian }\end{array}$}} & herd D & $6 \quad(6)$ & o (o) & $0 \quad(0)$ & o (o) \\
\hline & & I 75 herds & $8 \mathrm{I} \quad(7 \mathrm{I})$ & $26 \quad(17)$ & $34(2 \mathrm{I})$ & (I) \\
\hline \multicolumn{2}{|c|}{ British Friesian } & I 79 herds & I $02 \quad(90)$ & $3^{I} \quad(20)$ & $44 \quad(28)$ & (I) \\
\hline \multirow{2}{*}{\multicolumn{2}{|c|}{$\begin{array}{l}\text { British Friesian } \\
\text { British Friesian }\end{array}$}} & twins . & 20 (I6) & $8 \quad(4)$ & 14 (I0) & (o) \\
\hline & & experiment . & II (I I ) & $2 \quad(2)$ & $5 \quad(6)$ & (o) \\
\hline \multicolumn{2}{|c|}{ British Friesian } & 12 herds. & $3 \mathrm{I} \quad(26)$ & Io (6) & I9（I5） & (o) \\
\hline \multicolumn{2}{|c|}{ British White } & I herd & $0 \quad(0)$ & $\ldots$ & I (2) & 9 (10) \\
\hline Charollais & . & import & $3 \quad(3)$ & I $\quad(0)$ & $8 \quad(7)$ & $\ldots$ \\
\hline \multicolumn{2}{|c|}{ Danish Red . } & import & I (I) & o (o) & (I) & $0 \quad(0)$ \\
\hline \multirow{2}{*}{\multicolumn{2}{|c|}{$\begin{array}{l}\text { Dairy Shorthorn } \\
\text { Dairy Shorthorn }\end{array}$}} & twins & Io (9) & (o) & $2 \quad(2)$ & ... \\
\hline & & I07 herds & $74(66)$ & (6) & 18 (10) & $0 \quad(0)$ \\
\hline Devon & $\cdot$ & 30 herds & $5 \quad(7)$ & o (I) & Io (10) & $\ldots$ \\
\hline Galloway & · & I herd & $2 \quad(5)$ & $0 \quad$ (I) & 3 (I) & $5 \quad$ (5) \\
\hline Galloway & $\cdot$ & 8 herds & I $\quad$ (I) & $\cdots$ & I $\quad(0)$ & $3 \quad(2)$ \\
\hline $\begin{array}{l}\text { Guernsey } \\
\text { Guernsey }\end{array}$ & $\dot{.}$ & $\begin{array}{l}\text { I herd } \\
67 \text { herds }\end{array}$ & $\begin{aligned} 8 & (10) \\
22 & (22)\end{aligned}$ & $\begin{array}{ll}4 & \text { (3) } \\
5 & (4)\end{array}$ & $\begin{array}{rr}0 & (1) \\
14 & (14)\end{array}$ & $\begin{array}{l}\ldots \\
\ldots\end{array}$ \\
\hline Hereford & . & 99 herds & $35 \quad(24)$ & $26 \quad(13)$ & $4 I \quad(26)$ & o (o) \\
\hline Highland & . & I fold & 2 (I) & o (I) & I $\quad(0)$ & $3 \quad(2)$ \\
\hline $\begin{array}{l}\text { Jersey . } \\
\text { Jersey }\end{array}$ & $\dot{.}$ & experiment . & $23 \quad(22)$ & o (I) & o (I) & ... \\
\hline Jersey - & & 54 herds & $46(4 I)$ & $5 \quad(I)$ & (4) & $\cdots$ \\
\hline Lincoln Red & & 4 herds & $3 \quad(3)$ & $\cdots$ & (I) & $0 \quad(0)$ \\
\hline Longhorn & · & I herd & o (o) & I (2) & (8) & $\ldots$ \\
\hline Longhorn & & I herd & I (2) & I $\quad(\mathrm{I})$ & (6) & $\cdots$ \\
\hline N. Dairy Sh & orthor & 5 herds & $0 \quad(0)$ & I $\quad(2)$ & (o) & .. \\
\hline Red Poll & $\cdot$ & I herd & $7 \quad(7)$ & $0 \quad(0)$ & (o) & 2 (I) \\
\hline Red Poll & $\cdot$ & I I herds & (4) & $\ldots$ & (I) & o (I) \\
\hline South Devor & & I herd & $0 \quad(0)$ & $9 \quad(9)$ & o (I) & $\cdots$ \\
\hline South Devor & & 9 herds & $\begin{array}{ll}\mathrm{I} & (\mathrm{I}) \\
2 & \text { (I) }\end{array}$ & $\begin{array}{ll}4 & (5) \\
2 & (2)\end{array}$ & o (I) & $\cdots$ \\
\hline $\begin{array}{l}\text { Sussex . } \\
\text { Welsh Black }\end{array}$ & . & $\begin{array}{l}7 \text { herds } \\
\text { I } 2 \text { herds }\end{array}$ & $\begin{array}{ll}2 & (\mathrm{I}) \\
3 & (4)\end{array}$ & $\begin{array}{ll}2 & (2) \\
0 & (0)\end{array}$ & $\begin{array}{ll}0 & (0) \\
5 & (5)\end{array}$ & $\begin{array}{l}\cdots \\
\cdots\end{array}$ \\
\hline Sub total & . & single herd . & $26 \quad(24)$ & $6 \quad(5)$ & 14 (12) & o (2) \\
\hline Sub total & . & single herd . & $28 \quad(3 \mathrm{I})$ & I6 (17) & $20 \quad(22)$ & I9 (I 8) \\
\hline Sub total & . & many herds. & 345 (309) & $\operatorname{Iog}(64)$ & I 72 ( I 29) & (5) \\
\hline Sub total & . & many herds. & I 32 (I I9) & $34 \quad(27)$ & I Io $(99)$ & $5 \quad(5)$ \\
\hline Total & - & 969 herds & $531\left(4^{8} 3\right)$ & I 65 (I I 3$)$ & $3^{16}(262)$ & $29(30)$ \\
\hline
\end{tabular}

The cattle transferrin data tabulated above were significantly heterogeneous in more than one sense. Gene frequency differences occurred between breeds and occasionally between herds within breeds. In addition, some of the breed samples showed significantly excessive numbers of homozygotes. Asterisks indicate the five significant examples and their totals. 


\begin{tabular}{|c|c|c|c|c|c|c|c|c|}
\hline \multicolumn{6}{|l|}{ types } & \multirow{2}{*}{\multicolumn{3}{|c|}{$\begin{array}{c}\text { Test for Hardy-Weinberg } \\
\text { equilibrium }\end{array}$}} \\
\hline \multicolumn{6}{|c|}{ Heterozygotes } & & & \\
\hline Tf-a2dI & Tf-a2d 2 & Tf-aze & $T f-d_{1} d_{2}$ & Tf-die & $T f-d_{2} e$ & $x^{2}$ & d.f. & Probability \\
\hline I4 (23) & $5 \quad(6)$ & $2 \mathrm{I}(\mathrm{I} 6)$ & o $\quad(\mathbf{I})$ & I $\quad(4)$ & o (I) & $24 \cdot 53$ & 9 & $0.01-0.001 *$ \\
\hline $5 \quad(4)$ & $4 \quad(7)$ & o (2) & 3 (4) & I (I) & $3 \quad(\mathrm{I})$ & $5 \cdot 80$ & 9 & $0 \cdot 80-0 \cdot 70$ \\
\hline $20(22)$ & $34\left(3^{6}\right)$ & I I (IO) & $24 \quad(34)$ & $9 \quad(9)$ & I8 (I5) & II 22 & 9 & $0.30-0.20$ \\
\hline $25 \quad(27)$ & $3^{8} \quad(43)$ & II (I I) & $27 \quad\left(3^{8}\right)$ & IO (IO) & $2 I \quad(16)$ & $12 \cdot 8 I$ & 9 & $0 \cdot 20-0 \cdot 10$ \\
\hline $37(34)$ & $6_{7} \quad\left(6_{3}\right)$ & I6 (17) & $28 \quad(39)$ & 9 (II) & $22(20)$ & $8 \cdot 50$ & 9 & $0 \cdot 50-0 \cdot 30$ \\
\hline $\begin{array}{rr}21 & (19) \\
4 & (6)\end{array}$ & $26 \quad(38)$ & $6 \quad(8)$ & $23(22)$ & $8 \quad(5)$ & $7 \quad(9)$ & $\begin{array}{r}12 \cdot 55 \\
5.01\end{array}$ & 9 & $\begin{array}{l}0.20-0 \cdot 10 \\
0.90-0.80\end{array}$ \\
\hline $\begin{array}{rr}4 & (6) \\
62 & (59)\end{array}$ & $\begin{array}{r}\text { I6 (I9) } \\
\text { I09 (I2I) }\end{array}$ & $\begin{array}{rr}3 & (4) \\
25 & (29)\end{array}$ & $\begin{array}{ll}\text { I6 } & (14) \\
67 & (77)\end{array}$ & $\begin{array}{rr}4 & (3) \\
2 \mathrm{I} & (\mathrm{I} 8)\end{array}$ & $\begin{array}{rr}9 & (8) \\
3^{8} & \left(3^{8}\right)\end{array}$ & $\begin{array}{l}5 \cdot 01 \\
6 \cdot 36\end{array}$ & $\begin{array}{l}9 \\
9\end{array}$ & $\begin{array}{l}0.90-0.80 \\
0.80-0.70\end{array}$ \\
\hline $4 \quad(7)$ & I 5 (I I) & I (I) & $2 \quad(3)$ & $0 \quad(0)$ & o (o) & II $\cdot 04$ & 9 & $0 \cdot 30-0 \cdot 20$ \\
\hline o (3) & 9 (I0) & 2 (I) & $4 \quad(2)$ & $0 \quad(0)$ & o (I) & $8 \cdot 12$ & 9 & $0 \cdot 70-0 \cdot 50$ \\
\hline I I (I I) & I $3(\mathrm{I} 6)$ & & $7 \quad(9)$ & $\ldots$ & $\ldots$ & $4 \cdot 10$ & 5 & $0 \cdot 70-0 \cdot 50$ \\
\hline $2(2)$ & $\ldots$ & $5 \quad(4)$ & & 2 (I) & & $2 \cdot 25$ & 5 & $0.90-0 \cdot 80$ \\
\hline $0 \quad(\mathrm{I})$ & $3 \quad(3)$ & $2 \quad(2)$ & (I) & (o) & $(2)$ & $17 \cdot 3^{\overline{8}}$ & 9 & $0.05-0 \cdot 02$ \\
\hline I (I) & 3 (2) & $0 \quad(\mathrm{I})$ & o (o) & (o) & (o) & $12 \cdot 25$ & 9 & $0 \cdot 20-0 \cdot 10$ \\
\hline $64 \quad(69)$ & $62(78)$ & I6 (I5) & $27 \quad\left(3^{8}\right)$ & $5 \quad(7)$ & $9 \quad(8)$ & $21 \cdot 59$ & 9 & $0.02-0.01$ \\
\hline $\begin{array}{ll}78 & (85)\end{array}$ & $8 \mathrm{I}(\mathrm{IOO})$ & $23(2 \mathrm{I})$ & $34 \quad(47)$ & $8(10)$ & I2 (I2) & 25.53 & 9 & $0.01-0.00 I^{*}$ \\
\hline Io (I5) & $20 \quad(25)$ & $2(\mathrm{I})$ & 8 (12) & $0 \quad(0)$ & o (I) & I 5.66 & 9 & $0 \cdot 10 \cdot 0 \cdot 05$ \\
\hline Io $(9)$ & I5 (I6) & I $\quad(4)$ & $7 \quad(7)$ & $0 \quad(2)$ & 3 (I) & $14 \cdot 04$ & 9 & $0 \cdot 20-0 \cdot 10$ \\
\hline $20 \quad(24)$ & $35 \quad(40)$ & $3 \quad(3)$ & I5 (I 8) & o (i) & $3 \quad(2)$ & $8 \cdot 66$ & 9 & $0.5^{0-0} \cdot 30$ \\
\hline$\ldots$ & $2 \quad(2)$ & $4 \quad(4)$ & $\ldots$ & $\cdots$ & $9 \quad(8)$ & 0.95 & 5 & $0.9^{8-0.95}$ \\
\hline 2 (I) & $9 \quad(9)$ & $\ldots$ & o (2) & $\ldots$ & $\ldots$ & $6 \cdot 64$ & 5 & $0 \cdot 30-0 \cdot 20$ \\
\hline I (o) & (2) & o (I) & $0 \quad(0)$ & $0 \quad(0)$ & 2 (I) & $4 \cdot 9 \mathrm{I}$ & 9 & $0.90-0.80$ \\
\hline $4 \quad(4)$ & $6 \quad(8)$ & & $2 \quad(2)$ & $\ldots$ & & $I \cdot 10$ & 5 & $0.98-0.95$ \\
\hline $\begin{array}{ll}3^{T} & (39)\end{array}$ & $44 \quad(53)$ & $6 \quad(5)$ & 9 (I5) & I $\quad(I)$ & I (2) & $22 \cdot 43$ & 9 & $0.0 \mathrm{I}-0.00 \mathrm{I}^{*}$ \\
\hline $8 \quad(5)$ & I 7 (I6) & $\ldots$ & $5 \quad(6)$ & $\ldots$ & $\ldots$ & $3 \cdot 36$ & 5 & $0 \cdot 70-0 \cdot 50$ \\
\hline $6 \quad(4)$ & $5 \quad(5)$ & 12 (I0) & (2) & $4 \quad(4)$ & $2 \quad(5)$ & $9 \cdot 00$ & 9 & $0 \cdot 50-0.30$ \\
\hline$\ldots$ & $\mathrm{I} \quad(\mathrm{I})$ & $3 \quad(3)$ & $\ldots$ & $\ldots$ & o (2) & 4.00 & 5 & $0.70-0.50$ \\
\hline II (I I) & I I (7) & $\ldots$ & $3 \quad(4)$ & $\ldots$ & $\ldots$ & $4 \cdot 14$ & 5 & $0.70-0.50$ \\
\hline I9 (20) & $37 \quad(36)$ & $\ldots$ & I5 (I6) & $\ldots$ & $\cdots$ & $0 \cdot 2 \mathrm{I}$ & 5 & $>0.99$ \\
\hline $26 \quad(35)$ & $36 \quad(50)$ & I (I) & 2 I & I (I) & I (I) & $39 \cdot 62$ & 9 & $<0.00 I^{*}$ \\
\hline I (2) & $0 \quad(\mathrm{x})$ & $3 \quad(3)$ & 3 (I) & $2 \quad(2)$ & $0 \quad(2)$ & II $\cdot 85$ & 9 & $0 \cdot 30-0 \cdot 20$ \\
\hline I5 (Io) & 7 (II) & $\ldots$ & $2 \quad(2)$ & $\ldots$ & $\ldots$ & $7 \cdot 44$ & 5 & $0.20-0 \cdot 10$ \\
\hline $4(\mathrm{I} 3)$ & $26 \quad(25)$ & $\ldots$ & $3 \quad(4)$ & $\cdots$ & $\cdots$ & $22 \cdot 89$ & 5 & $<0.001^{*}$ \\
\hline$\ldots$ & $2 \quad(3)$ & 2 (I) & $\ldots$ & $\ldots$ & o (I) & I 67 & 5 & $0.90-0.80$ \\
\hline I $\quad(0)$ & o (I) & $\ldots$ & $7 \quad(7)$ & $\ldots$ & $\ldots$ & $2 \cdot 5 \mathrm{I}$ & 5 & $0 \cdot 80-0 \cdot 70$ \\
\hline o (3) & (6) & $\ldots$ & $8 \quad(5)$ & $\cdots$ & $\cdots$ & $9 \cdot 6$ & 5 & $0 \cdot 10-0.05$ \\
\hline 2 (I) & $0 \quad(0)$ & $\ldots$ & 2 (I) & $\ldots$ & $\ldots$ & $2 \cdot 22$ & 5 & $0 \cdot 90-0 \cdot 80$ \\
\hline I (o) & o (2) & $6 \quad(6)$ & $0 \quad(0)$ & $0 \quad(0)$ & o (I) & II $\cdot 20$ & 9 & $0 \cdot 30-0 \cdot 20$ \\
\hline & (5) & $4 \quad(4)$ & & $\ldots$ & $4 \quad(2)$ & $4 \cdot 10$ & 5 & $0 \cdot 70-0 \cdot 50$ \\
\hline $2 \quad(2)$ & (I) & $\ldots$ & (5) & $\ldots$ & $\ldots$ & $\mathrm{I} \cdot 04$ & 5 & $0.98-0.95$ \\
\hline 3 (3) & (2) & $\ldots$ & (5) & $\cdots$ & $\ldots$ & $3 \cdot 1 \overline{6}$ & 5 & $0 \cdot 70-0 \cdot 50$ \\
\hline $2 \quad(3)$ & I $\quad(\mathrm{I})$ & $\ldots$ & 2 (I) & $\ldots$ & $\ldots$ & $4 \cdot 50$ & 5 & $0 \cdot 50-0 \cdot 30$ \\
\hline I $\quad(0)$ & Io $(9)$ & $\ldots$ & o (I) & $\ldots$ & $\cdots$ & I. 52 & 5 & $0.95-0.90$ \\
\hline I9（I9） & $23 \quad(27)$ & $7 \quad(8)$ & IO (I4) & $4 \quad(3)$ & $6 \quad(3)$ & $7 \cdot 89$ & 9 & $0 \cdot 70-0 \cdot 50$ \\
\hline $22 \quad(25)$ & $38 \quad(34)$ & $27 \quad(24)$ & $3^{1} \quad(26)$ & $6 \quad(6)$ & II (I6) & $4 \cdot 32$ & 9 & $0 \cdot 90-0 \cdot 80$ \\
\hline $197(236)$ & $292(334)$ & $64 \quad(55)$ & I 5 (I6o) & I 7 (24) & $35 （ 35 ）$ & $78 \cdot 06$ & 9 & $<0.001^{*}$ \\
\hline I05 (I04) & I $72($ I 92$)$ & $29 \quad(33)$ & 88 (เо3) & 2I (I9) & $4^{\mathrm{I}} \quad\left(4^{\mathrm{I}}\right)$ & $9 \cdot 43$ & 9 & $0 \cdot 70-0 \cdot 5^{0}$ \\
\hline $343\left(3^{84}\right)$ & $525\left(5^{87}\right)$ & I 27 (I 20) & $244\left(3^{02}\right)$ & $4^{8} \quad\left(5^{I}\right)$ & $93 \quad(95)$ & $58 \cdot 8 \mathrm{I}$ & 9 & $<0.001^{*}$ \\
\hline
\end{tabular}

Although table 2 contains different breeds and herds, it does not present any statistical comparison of their gene frequencies. Such comparisons are made and tested in later tables. Gene frequency differences between certain herds could be responsible for the apparent genetic imbalance found in some breeds. 
regarded as breeding units in which transient genetic isolation could occur if matings were more frequent within herds than between herds.

A population shows genetic equilibrium when the observed number of genotypes approximate to the numbers calculated using the HardyWeinberg model. The numbers of transferrin types seen in 22 breeds are shown in table 2. The table also gives the numbers of herd sources. The expected numbers shown in brackets were obtained by using the gene frequency data implicit in each population or sub-population. A statistical test applied to each row of data gave a $\chi^{2}$ value and a probability, $\mathrm{P}$, shown towards the right of table 2. The breeds are in alphabetical order.

Genetic equilibrium of transferrin genes occurred in groups of cattle born in single herds. The I 4 single herd sources indicated within table 2 were the A.I. bulls from Ayrshire herd A and from British Friesian herds A, B, C and D, also groups of cattle born in single herds of Belted Galloway, British White, Galloway, Guernsey, Highland, Red Poll, South Devon, and in the two herds of the Longhorn breed. All showed genetic equilibrium at the Tf locus. The I4 single herds belonged to nine of the 22 breeds in table 2. They included examples of herds contributing much genetic material through A.I. to commercial dairy and beef herds and examples of obscure breeds. All of the 14 examples were combined in the first two rows of the sub-totals below table 2.

The majority of the breed samples in table 2, particularly those containing large numbers of A.I. bulls, originated in many herds, and several of those breed samples contained excessive numbers of homozygotes, and correspondingly deficient numbers of heterozygotes. This apparent lack of equilibrium was most pronounced in five breed samples, all composed of A.I. bulls. The probability values were $\mathrm{P}<0.001$ in Hereford and Jersey and $\mathrm{P}<0.01$ in Aberdeen Angus, British Friesian and Dairy Shorthorn. The pedigrees of the bulls showed that this was attributable to Wahlund's effect. Genetic isolation was less apparent within the Ayrshire and Guernsey breed samples. Those also contained large numbers of bulls from many herd sources but showed genetic equilibrium. The remaining I2 breeds, represented by fewer tested bulls, did not show a significant departure from Hardy-Weinberg expectations.

Cows born in many herds and mostly sired by A.I. bulls were used in experiments where random selections of cow genotypes were favoured. Those formed the remaining category in table 2. They included $49 \mathrm{I}$ Ayrshire, 136 Friesian, 24 Dairy Shorthorn and 47 Jersey cows. None showed genetic imbalance. All are combined in the last sub-total below table 2 .

The overall type totals in the final row of table 2 showed very significant imbalance although allowance was made for genetic differences between breeds. Most of this imbalance was due to the A.I. bulls in the five significant breed samples. 







\section{(ii) Gene frequencies in herds within breeds}

The random mating usually assumed in natural populations may be prevented in enclosed domestic herds where most of the male calves are slaughtered or castrated. The progeny of the polygamous matings of one or a few stock bulls or a few nominated A.I. sires may disturb the genetic composition of a herd or a breeding population of cattle, and similar genetic effects could be due rarely to selectively favoured cows, but polygamous matings do not inevitably lead to disturbed gene frequencies. Changes are improbable wherever a sufficient number of random genotypes are involved. This may be achieved by design in experimental herds or by chance due to varied matings in some commercial herds. The tested cattle contained a wide range of examples of populations with different breeding structures.

In nine British breeds, subpopulations of appreciable size were available for statistical comparisons within breeds. Each of those nine breeds were allocated two or more rows in table 2 and they reappear in table 3 which is concerned only with the numbers of the distinct varieties of haploid transferrin allelomorphs, regardless of the genotypes in which they were observed. Nineteen of the most meaningful comparisons were tested using $2 \times j$ contingency tables (Mather, 195I). Each comparison contained numerical data on two sub-populations with $j$ equal to three or four allelomorphs.

Among the British Friesian samples, the proportions of the transferrin allelomorphs observed in each of three breeding herds which had produced large numbers of bulls used in A.I. differed significantly from the remaining bulls in this breed. (Herd $\mathrm{A}, \mathrm{P}<\mathrm{0} \cdot \mathrm{or}$; herd $\mathrm{B}$, $\mathrm{P}<\mathrm{O} \cdot$ oor and herd $\mathrm{C}, \mathrm{P}<\mathrm{O} \cdot \mathrm{OI})$. The transferrin allelomorph frequencies in the Friesian bulls differed slightly from those for the Friesian cows in the three experimental herds $(\mathrm{P}<0 \cdot 05)$.

Females were predominant among the available sub-populations of the Ayrshire breed sample, which was less heterogeneous than the Friesians. One experimental group of Ayrshire cows and one private herd of Guernsey cows were slightly atypical of their respective breeds $(\mathrm{P}<0.02$ in both).

In the two Longhorn herds the proportions of transferrin genes differed significantly $(\mathrm{P}<0 \cdot 02)$. The two Longhorn herds shared the same set of three allelomorphs and were known to have exchanged animals in recent years, but many of the cattle in the Claybrooke herd were sired by a bull which had transmitted $\mathrm{Tf}^{\mathrm{d} 2}$ while the contemporary bull in the Whipsnade herd had transmitted Tfa. The Longhorn herds provide a good example of genetic drift.

In each of the five remaining breeds in table 3, two sub-populations were compared, and no genetic difference was revealed.

The majority of the tested bulls were single representatives of breeders' herds, but each of 59 herds produced more than three bulls sampled at the centres. The transferrin gene frequency statistics for 
TABLE 4

Transferrin gene frequency estimates for some of the prominent sources of the A.I. bulls used recently in Britain

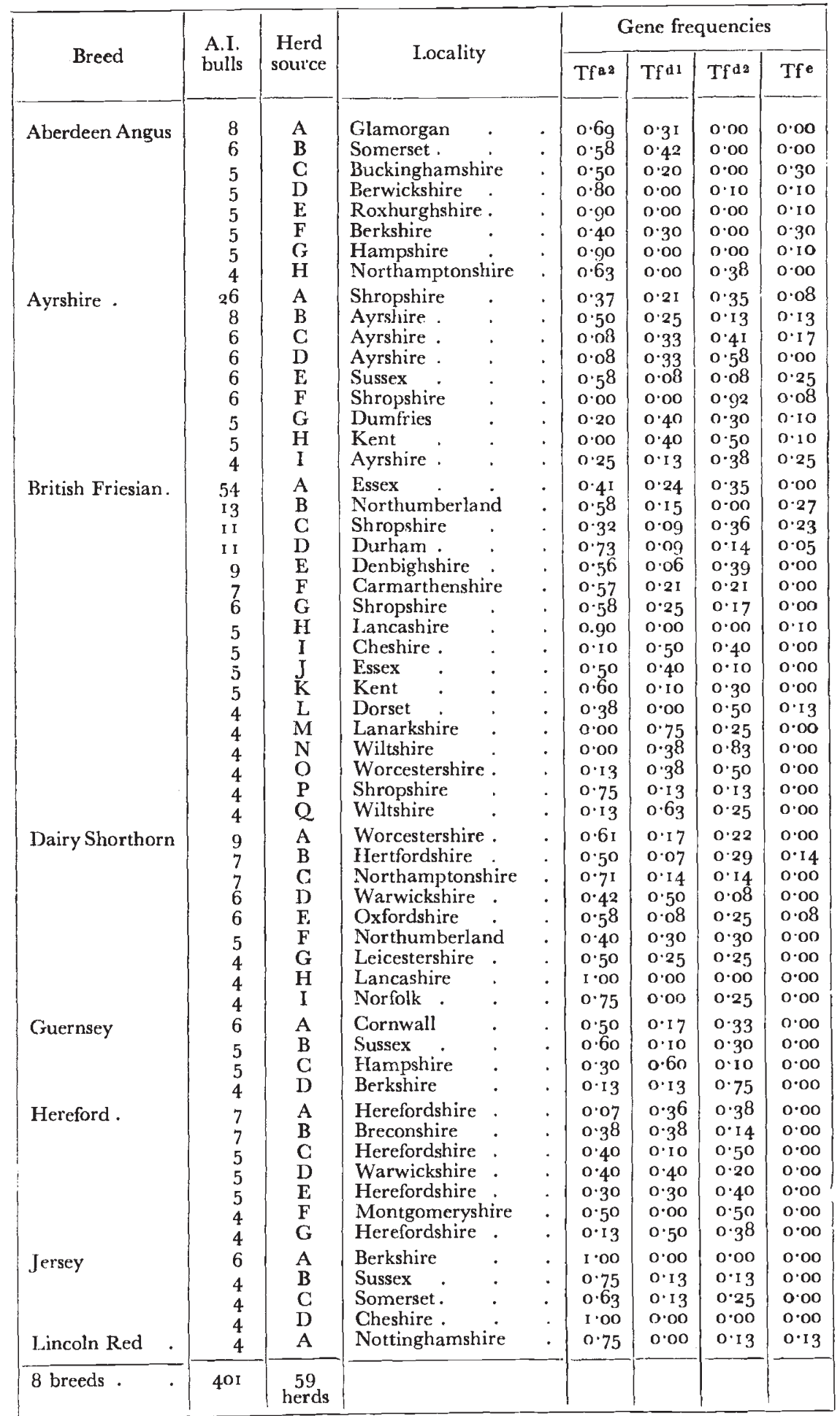




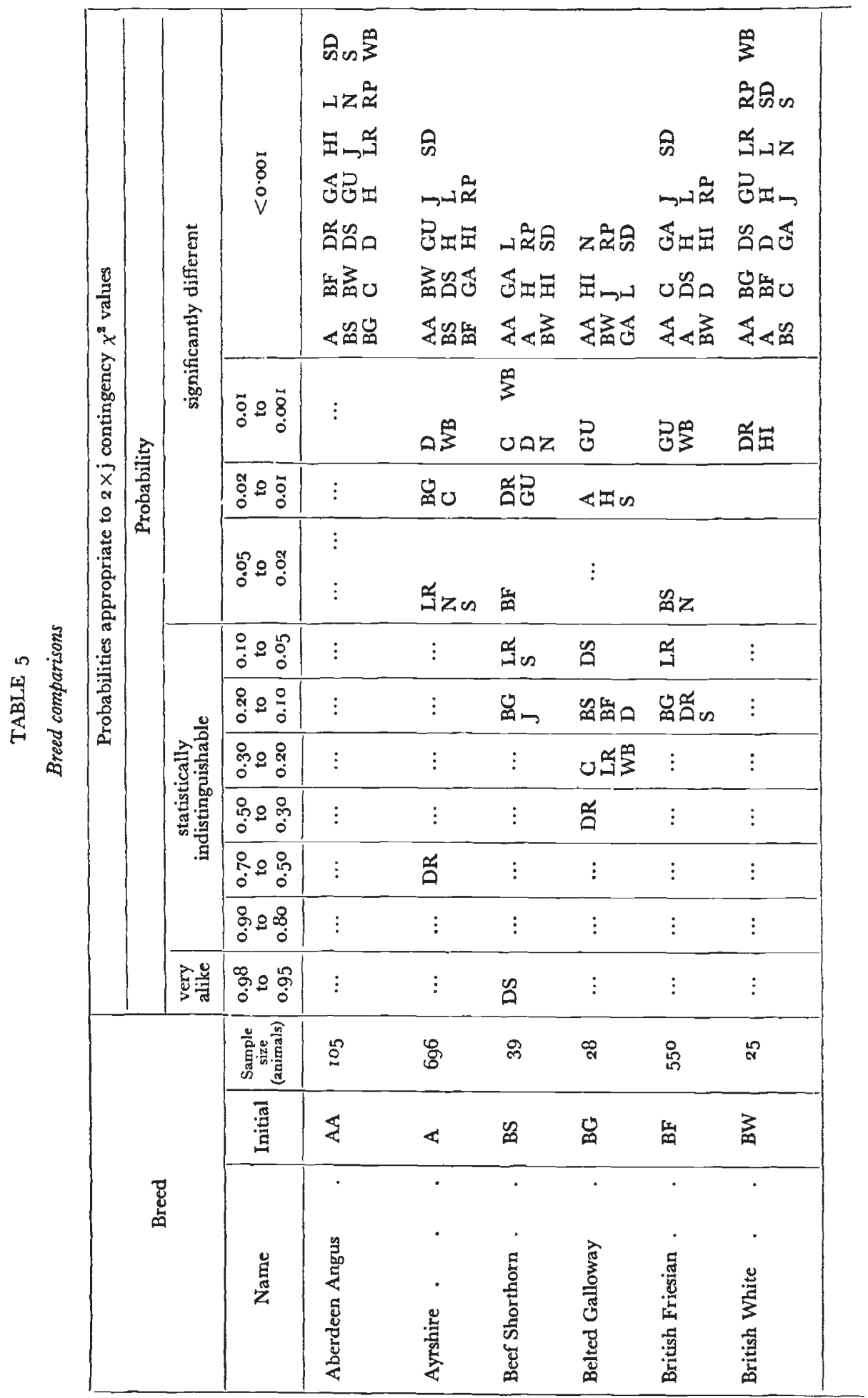




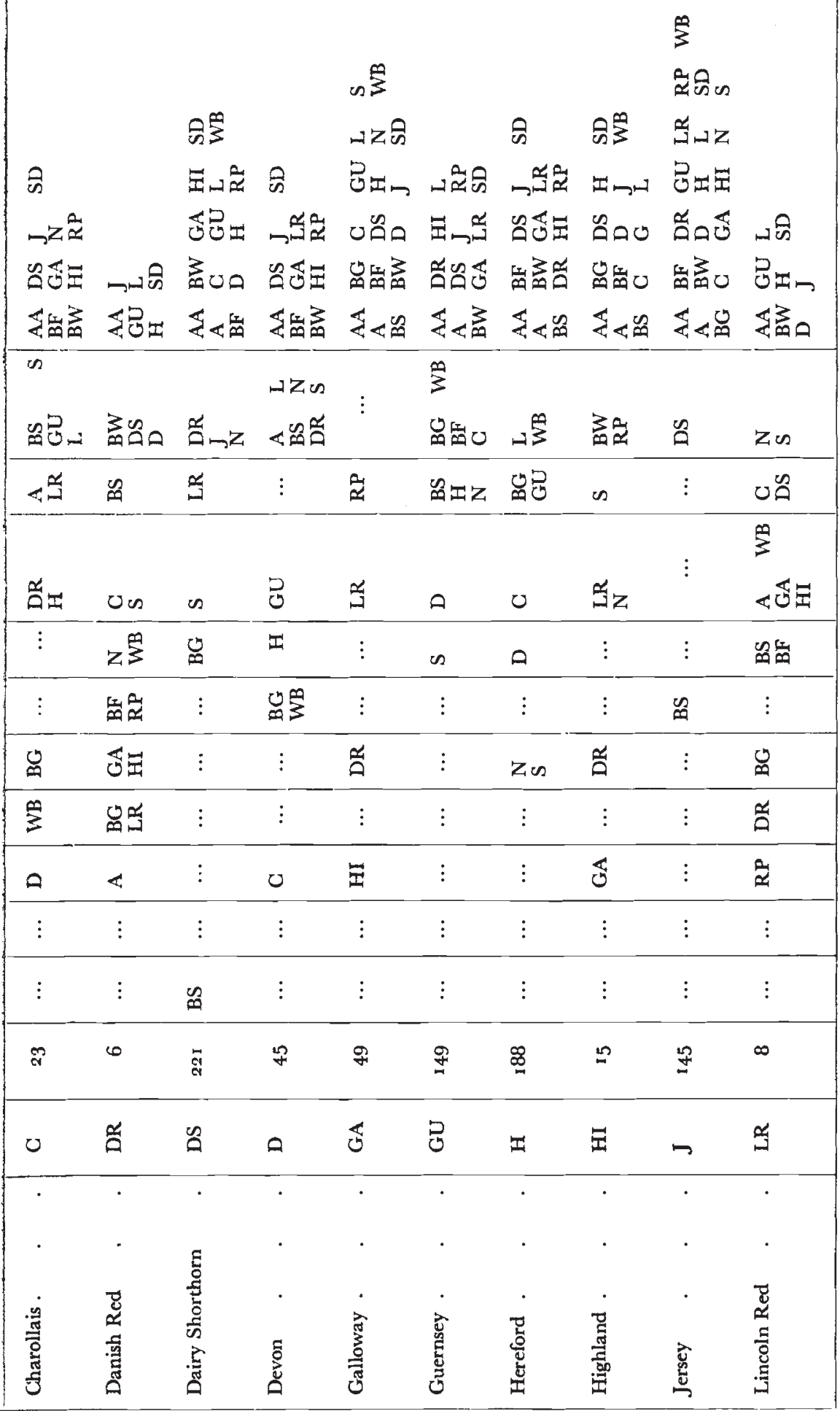


A. JAMIESON

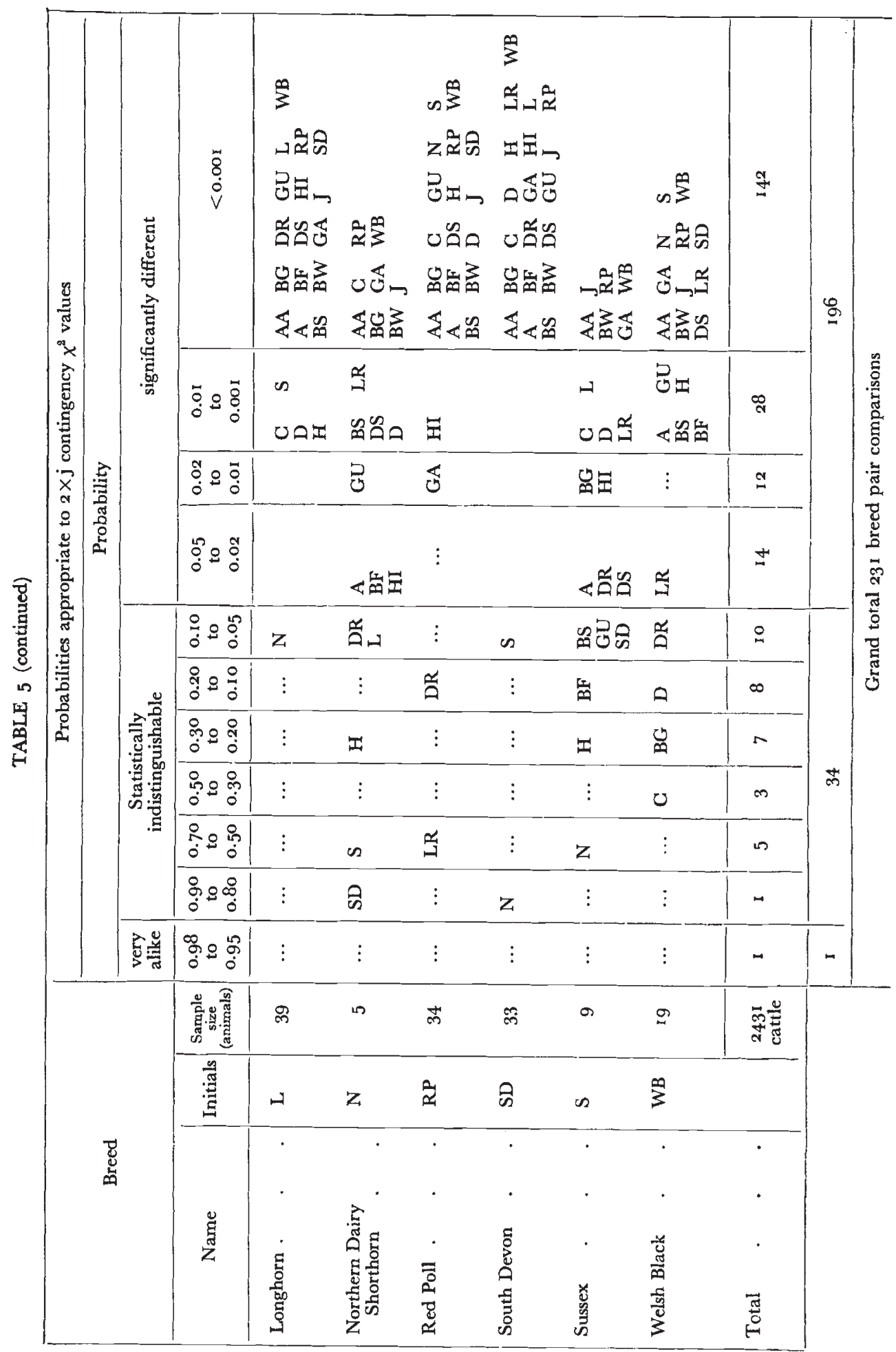


those larger herd samples are shown in table 4. Eight breeds were represented. The 59 herd sources were coded alphabetically within breeds. The five largest herd samples were described and compared already in tables 2 and 3 . Each of the remaining tabulated herds had fewer than io bulls tested.

The British Friesian breed was represented by more herds than any other, and one of them (herd A) was the source of 54 bulls. The allele Tf e appeared in no tested bull born in this herd. Most of herd A were descended from one bull imported from South Africa, and presumably he did not transmit $\mathrm{Tf}^{\mathrm{e}}$. In contrast to its rarity in herd $\mathrm{A}, \mathrm{Tf}^{\mathrm{e}}$ was found in 7 of the 13 tested bulls originating in herd $B$, and in 5 of I I bulls from herd $\mathrm{C}$. The herd B sample contained no Tf ${ }^{\mathrm{d} 2}$, herds $\mathrm{C}$ and $\mathrm{D}$ showed very few examples of $\mathrm{Tf} \mathrm{d}^{\mathrm{d}}$, and the majority of transferrin alleles in herd D were Tf ${ }^{a}$. Drifting gene frequencies in those herds and in the remaining Friesian herds were indicated by the excess of homozygous bulls in this breed in table 2 .

The tested bulls from Ayrshire herd A showed transferrins typical of their breed, and the small numbers of bulls in the 54 remaining herd samples in table 4 allowed larger sampling errors and gave no significant statistical comparison, but they were evidence that the transferrin variation seen in all breeds extended to most, and possibly to all herds. In the Dairy Shorthorn and Jersey breeds three monomorphic herd samples occurred, but those probably resulted from the limited sample sizes.

\section{(iii) Genetic difference between cattle breeds in the U.K.}

The electrophoretic technique disclosed the homozygous or heterozygous transferrin genotype in each tested animal. Gene populations containing different numbers of specified varieties of Tf genes were counted in 22 breeds in Britain; the number of Tf genes in each were shown in table 2. The numbers in each breed were compared with those in each of the 21 remaining breeds, giving a total of 231 comparisons. The data in each comparison were contained in a $2 \times j$ table for 2 breeds and $j$ genes, and contingency $\chi^{2}$ values with $j$-I degrees of freedom were calculated for each comparison (Mather, I95I). A summary of the probabilities obtained is shown in table 5 , in which the breeds are given in alphabetical order and initial letters are used to distinguish the breed comparisons. A scale of probability thresholds along the top of the table indicates the likelihood of using the available transferrin data to demonstrate differences between breeds.

Many highly significant genetic differences were found by comparing the transferrins in the 22 breeds. The total numbers of comparisons are shown beneath the columns in table 5. Probability values of $\mathrm{P}<0.00$ I were obtained for $6 \mathrm{I}$ per cent. of the total breed pair comparisons, and 85 per cent. of the same total were within the $\mathrm{P}<\mathrm{O}^{\circ} \mathrm{O}_{5}$ 
level of significance. The breed comparisons which failed to show significant differences were 5 per cent. of the total, and these involved breeds represented by few specimens. A solitary example of a pair of breeds having transferrin genes showing significantly similar proportions $(\mathrm{P}>0.95)$ was Beef Shorthorn and Dairy Shorthorn, both contained in Coates Herdbook. Otherwise, the table displays the genotypic diversity of the cattle breeds in the United Kingdom. This variation is illustrated in figure 2 where the gene frequencies appear as segments of circles.

A general decrease in the frequency of $\mathrm{Tf}^{\mathrm{e}}$ from north to south in fig. 2 was interrupted by the British White, Lincoln Red, and Red Poll breeds having more $\mathrm{Tf}^{\mathrm{e}}$ than the adjacent breeds. The same three breeds showed no $\mathrm{Tf}^{\mathrm{d}}$.

The historical accounts of cattle in Britain describe successive importations of cattle and massive droves from the extremities of the land towards the seaports and population centres, mainly to London. The absence of genetic uniformity in the wake of those movements suggests that the local varieties with which the migrant droves may have bred were largely lost when the modern breeds were founded. Many of the breeds are known to be the numerical expansion of limited numbers of selected foundation animals. In this way the differences between breeds could originate in differences such as those already seen between isolated herds within breeds in tables 3 and 4 . The genetic limitations of the foundation stock, or any other temporary reduction in the effective breeding numbers, may influence the future genetic structure of a breed (Lush, 1946). One likely example is the Aberdeen Angus breed which has unique Tf gene frequencies, and a pedigree study traced a quarter of the genes in this breed to one bull (Stonaker, 1943).

There are examples of the transferrin types indicating genetic affinities which cut across differences in the commercial purposes of distinct breeds. The following examples show this in two regions. The Ayrshire, Galloway and Highland breeds show four transferrin genes in roughly similar proportions, but the Ayrshire breed is almost exclusively for dairy produce and the other Scottish breeds are primarily for beef. The next example is more remarkable. The breeds from Wales, Southern England, the Channel Islands and France share a set of three transferrin genes, although each breed has been selected for the specialised production of beef or butterfat or for draft purposes, as in Sussex, and most have a distinctive outward appearance.

Similarities between obscure breeds could imply common ancestry, just as differences could be used to dispute their genetic relationships. For example, the transferrin data may be used to support the view that the Red Poll breed is related to some Scandinavian breeds. Similarly the Highland and Galloway breeds may be regarded as descended from one stock distinct from the English Longhorn and Welsh Black breed which belong to the Southern Community of breeds in fig. 2. 


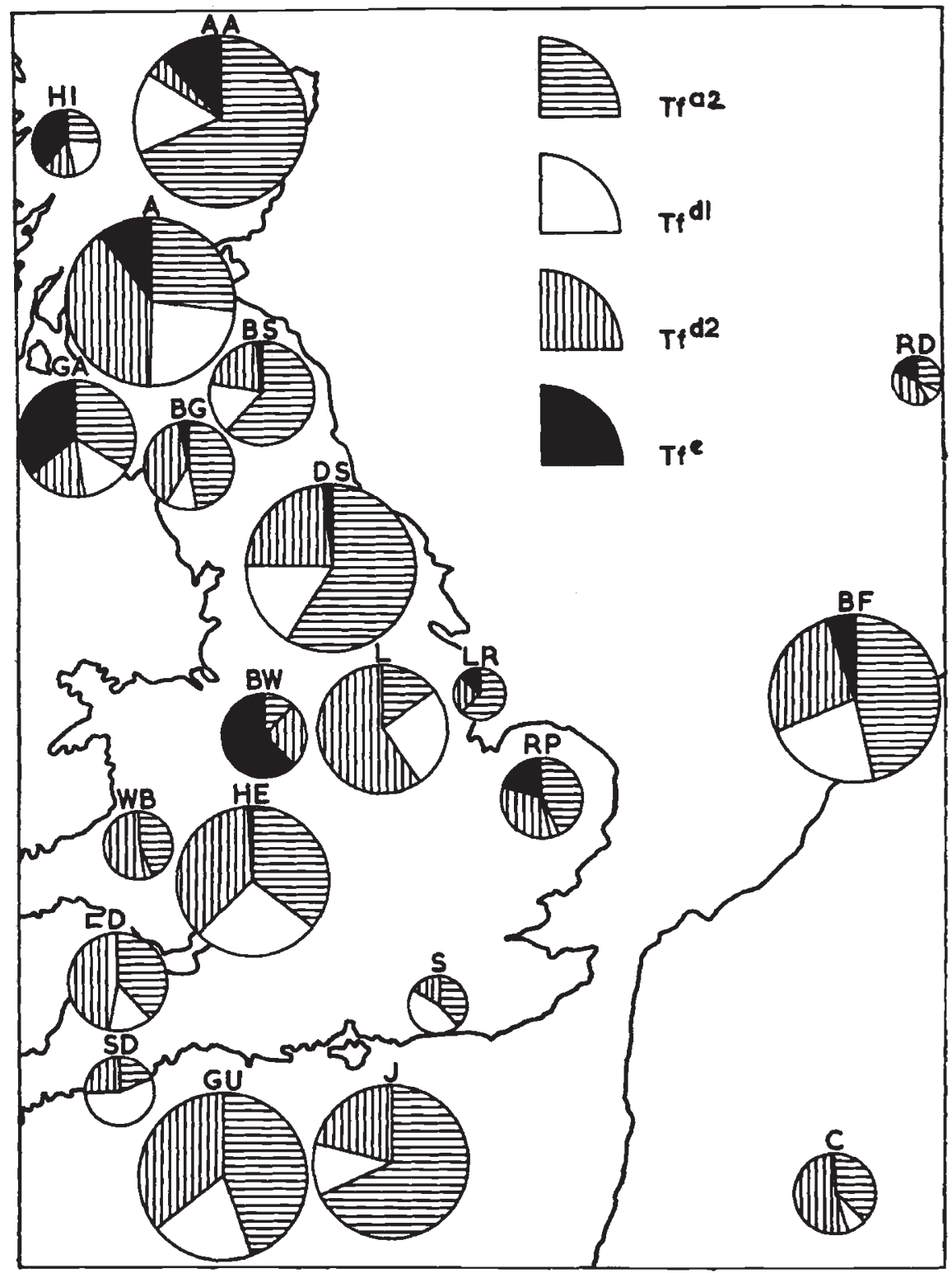

Fic. 2.-Cattle breeds were represented by their initial letters:

A Ayrshire
AA Aberdeen Angus
BF British Friesian
BG Belted Galloway
BS Beef Shorthorn
BW British White
C Charollais

D Devon

DS Dairy Shorthorn

GA Galloway

GU Guernsey

HE Hereford

HI Highland

J Jersey
L Longhorn

LR Lincoln Red

RD Red Dane

RP Red Poll

$S$ Sussex

SD South Devon

WB Welsh Black

Fig. 2.-The geographic distribution of allelomorphic genes at the $\mathrm{Tf}$ locus in 2 I breeds of cattle are represented on a map of England and the adjacent territories. The positions of circles on the map indicate the probable geographical origins of the breeds, and the areas of the circles indicate the numbers of cattle tested. Six uniformly large circles represent those breeds samples exceeding 100 cattle, and the scale of lesser circles inlcate breed samples of fewer than roo cattle. E.g. The smallest sample, six Red Dane bulls, had four Tfa ${ }^{2}$, one Tfdl, five $\mathrm{Tf}^{\mathrm{d}}{ }^{2}$ and two Tf ${ }^{\mathrm{e}}$ allelomorphs, represented proportionately by segments of $120^{\circ}, 30^{\circ}, 150^{\circ}$ and $60^{\circ}$ respectively. 
The transferrin data may help to resolve conflicting opinions. For example, the Ayrshire breed could be largely descended from native Scottish cattle (Buchanan-Smith, 1937) or could owe more to Channel Island, Dutch and Shorthorn genes (Trow-Smith, 1959). The transferrin locus evidence tends to support the view that the Ayrshire breed is genotypically closer to the Highland and Galloway breeds.

(iv) The world-wide distribution of bovine Tf genes

The bovine transferrin gene frequency estimates currently known to the author are presented for the domestic humpless cattle of Europe, Bos primigenius f.d. taurus Linnaeus, in table six, and for the domestic zebu, Bos primigenius f.d. indicus Linnaeus and its derivatives, in table 7. The zebu contained at least two Tf allelomorphs not reported in other cattle. Rare Tf allelomorphs occurring with frequencies of less than 0.005 were not tabulated. The references confined to tables 6 and 7 apply to the findings of tests in nineteen scattered laboratories. The sizes of the breed samples and the numbers of their herd sources were inserted where known. The stated countries refer to the places where the cattle were born, and may not coincide with the countries where the breeds were formed. Several breed samples were dispersed over different countries. The known origins of domestic stock are available in a dictionary of breeds (Mason, 1957).

Although the earlier samples were not tested in the same detail as the recent samples, all of the available European cattle data were accommodated within table 6 by tabulating the frequencies of $\mathrm{Tf}^{\mathrm{d} 1}$ and $\mathrm{Tf}^{\mathrm{d} 2}$ separately where possible, or adding them together under $\mathrm{Td}^{\mathrm{d}}$ where this distinction was not made. The subheadings $\mathrm{Tf} \mathrm{d}^{\mathrm{1}}$ and Tf ${ }^{d^{2}}$ were not used in table 7 , because no such detail is yet available for zebu.

In the following paragraphs, each of the eight known allelomorphic genes controlling the transferrins in cattle blood sera is considered in turn. The order of presentation is that of their relative electrophoretic mobilities in gelled starch, from fast to slow, using the revised notation (Jamieson, 1965).

$T f^{a}$. A transferrin pattern with a herd gene frequency of $0 \cdot 003$ was reported in one family within a herd of Boran cattle in Kenya (Ashton and Lampkin, 1965a). A similar, presumably identical, infrequent gene in Piedmont cattle in Italy was found by Sartore $e t$ al. (1963) and confirmed in the same material by the author. If those two mutants are identical their ethnic significance may become apparent when other Mediterranean breeds are tested. Ashton and Lampkin used the letter $\mathrm{G}$ to describe this gene, but this letter had already been used by Osterhoff (1964) to describe another Tf gene in cattle. The present notation avoids ambiguity.

$T f^{a 2}$. Apart from a few small samples, this gene appeared in all herds of all breeds tested. The highest frequencies were 0.69 in Aberdeen Angus and in Jersey cattle. High frequencies were also found in 


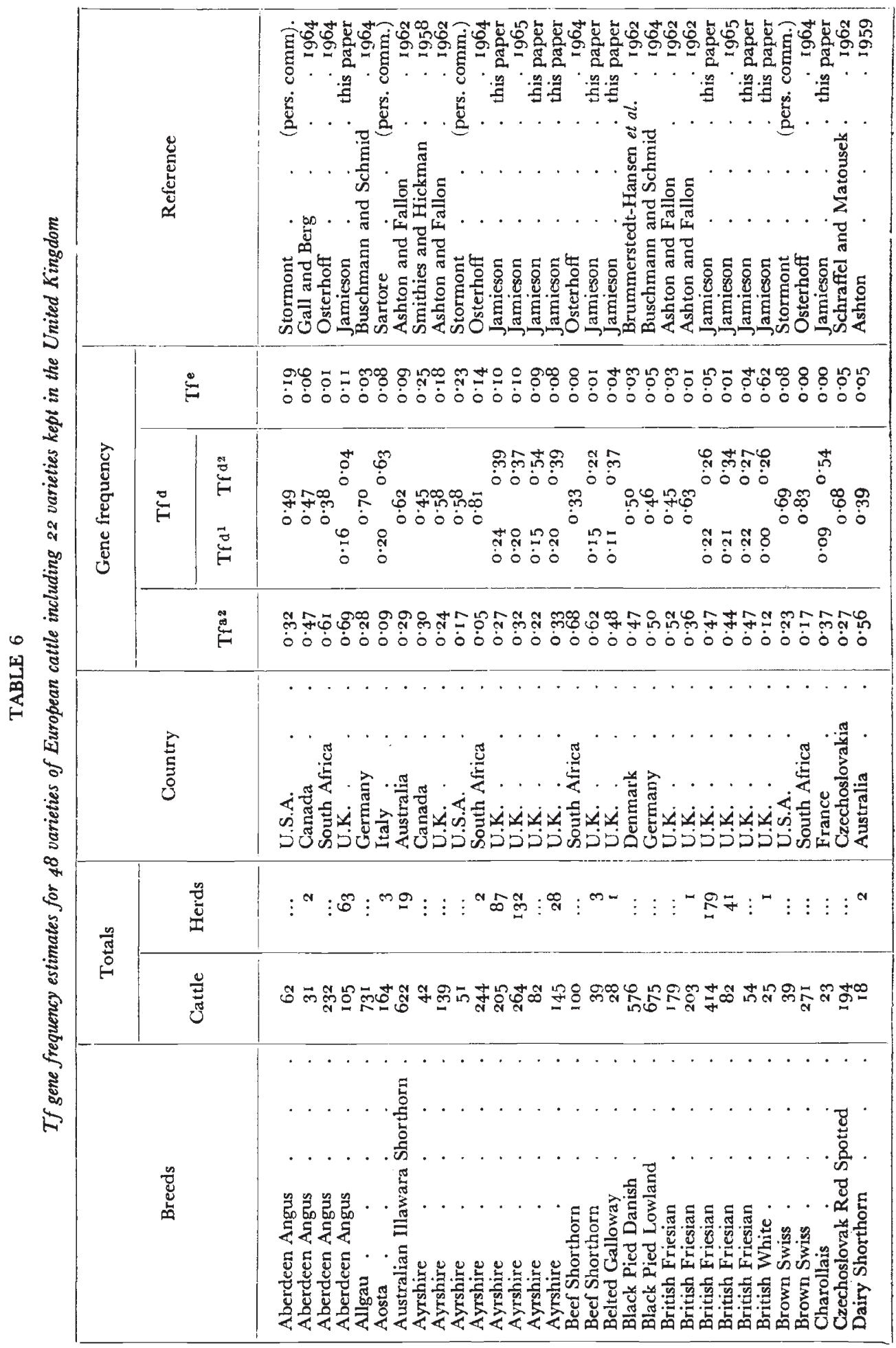









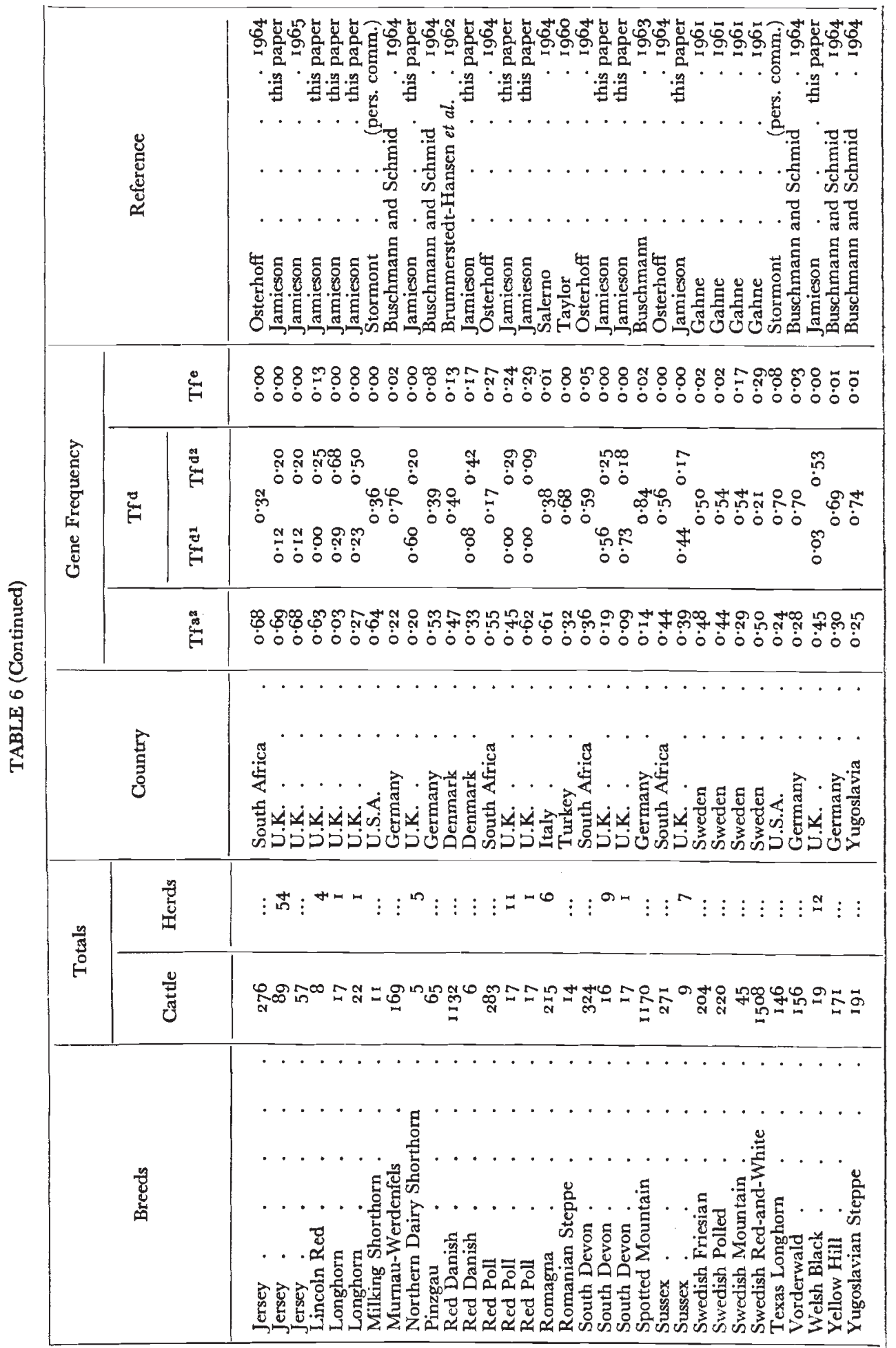


Dairy Shorthorn at 0.58 , while Beef Shorthorn and a small sample of Lincoln Red Shorthorn bulls each showed $0 \cdot 62$. The gene was not common in South Devon cattle, of which I6 bulls showed o. I9 and I 7 cows in a single herd showed 0.06 .

This gene, $\mathrm{Tf}^{a}{ }^{2}$, was common in most zebu cattle and in breeds with zebu affinities, but the Boran and Sahiwal herds tested in East Africa showed frequencies of 0.08 and 0.07 respectively.

TABLE 7

The transferrin gene frequencies reported in fifteen varieties of Asiatic and African cattle are tabulated alphabetically with references. This table contains all of the known estimates of $T f^{b}$ and $T f^{\prime}$. Those two genes have not been reported in any of the 49 European breeds described in table 6 . The distinction between $T f^{{ }^{d}{ }_{1}}$ and $T f^{d 2}$ has not been made as yet in zebus

\begin{tabular}{|c|c|c|c|c|c|c|c|c|c|}
\hline \multirow{2}{*}{\multicolumn{2}{|c|}{ Breed }} & \multirow{2}{*}{$\begin{array}{c}\text { No. } \\
\text { of } \\
\text { ani- } \\
\text { mals }\end{array}$} & \multirow{2}{*}{ Country } & \multicolumn{5}{|c|}{ Gene frequency } & \multirow{2}{*}{ References } \\
\hline & & & & $\mathrm{Tf}^{\mathrm{a} 2}$ & Tf $b$ & Tf $d$ & Tf e & $\mathbf{T f}^{\mathrm{f}}$ & \\
\hline \multirow{2}{*}{\multicolumn{2}{|c|}{ Afrikaner }} & 223 & South Africa & 0.40 & $0 \cdot 00$ & 0.33 & $0 \cdot 27$ & $0 \cdot 00$ & Osterhoff $\quad . \quad .1964$ \\
\hline \multirow{2}{*}{\multicolumn{2}{|c|}{$\begin{array}{l}\text { Anatolian Black } \\
\text { Ankole. }\end{array}$}} & 22 & Turkey . & $0 \cdot 34$ & $0 \cdot 00$ & $0 \cdot 18$ & $0.4 \mathrm{I}$ & $0 \cdot 07$ & \multirow{2}{*}{$\begin{array}{l}\text { Taylor . (pers. comm.) } \\
\text { Ashton and Lampkin } 1965^{b}\end{array}$} \\
\hline & . & 267 & East Africa & 0.24 & $0 \cdot 09$ & $0 \cdot 09$ & 0.37 & 0.21 & \\
\hline Bonsmara & . & 96 & South Africa & 0.45 & $0 \cdot 00$ & $0 \cdot 36$ & $0 \cdot 19$ & $0 \cdot 00$ & Osterhoff . . I 964 \\
\hline Boran . & . & 102 & East Africa & o.19 & 0.02 & $0 \cdot 56$ & 0.23 & $0 \cdot 01$ & Osterhoff $\quad \therefore \quad 1964$ \\
\hline Boran & . & 265 & East Africa & $0 \cdot 08$ & $0 \cdot 07$ & 0.19 & 0.29 & $0 \cdot 37$ & Ashton and Lampkin $1965 b$ \\
\hline Brahman & . & few & Australia. . & $0 \cdot 30$ & $0 \cdot 00$ & 0.10 & 0.30 & $0 \cdot 30$ & Ashton \& . . 1959 \\
\hline Drakensberg & 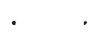 & 185 & South Africa & 0.31 & $0 \cdot 00$ & $0 \cdot 49$ & $0 \cdot 20$ & $0 \cdot 00$ & Osterhoff \\
\hline East Turkish & & 10 & Turkey . & $0 \cdot 25$ & $0 \cdot 15$ & 0.25 & $0 \cdot 15$ & 0.20 & Taylor . (pers. comm.) \\
\hline \multicolumn{2}{|c|}{ Eastern Province Zebu } & 72 & East Africa & 0.18 & 0.04 & $0 \cdot 12$ & 0.34 & 0.33 & \multirow{2}{*}{$\begin{array}{l}\text { Ashton and Lampkin } 1965 b \\
\text { Ashton and Lampkin } 1965 b\end{array}$} \\
\hline Nganda . & $\cdot \quad \cdot$ & $13^{8}$ & East Africa & 0.42 & $0 \cdot 09$ & $0 \cdot 12$ & 0.21 & 0.17 & \\
\hline Nguni $\therefore$ & . & 100 & South Africa & $0 \cdot 39$ & $0 \cdot 00$ & $0 \cdot 27$ & 0.33 & $0 \cdot 00$ & Osterhoff $\quad \cdot \quad \cdot 1964$ \\
\hline Red Sindhi & - & I 4 & Australia . & 0.57 & 0.04 & 0.00 & $0 \cdot 28$ & $0.1 \mathrm{I}$ & Ashton . \\
\hline Sahiwal . & & 10 & Australia . & $0 \cdot 10$ & 0.20 & $0 \cdot 00$ & $0 \cdot 15$ & 0.55 & Ashton : . $\quad$ I959 \\
\hline Sahiwal . & & 228 & East Africa & 0.07 & $0 \cdot 10$ & $0 \cdot 25$ & $0 \cdot 22$ & $0 \cdot 3^{8}$ & Ashton and Lampkin $1965 b$ \\
\hline $\begin{array}{l}\text { South Anato } \\
\text { Tanganyika }\end{array}$ & $\begin{array}{l}n \text { Red } \\
\text { bu }\end{array}$ & 12 & $\begin{array}{l}\text { Turkey } \\
\text { East Africa }\end{array}$ & $\begin{array}{l}0.38 \\
0.22\end{array}$ & $\begin{array}{l}0.00 \\
0.04\end{array}$ & $\begin{array}{l}0.46 \\
0.15\end{array}$ & 0.13 & 0.04 & Taylor - (pers. comm.) \\
\hline & & & Last Rinta & $0 \cdot 22$ & 0.04 & 0.15 & 0.20 & 039 & 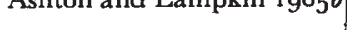 \\
\hline
\end{tabular}

$\tau f^{b}$. No example of this gene has been reported in any European breed. It was first found in Indian cattle kept in Australia. It has since been found at low frequency in seven breeds in East Africa and in the East Turkish breed. All of the breeds containing T $f^{b}$ also had $\mathrm{Tf}^{\mathrm{f}}$ which was invariably more frequent than $\mathrm{Tf}^{\mathrm{b}}$.

$T f^{d}$. Where the faster $\operatorname{Tf}^{\mathrm{d} 1}$ and the slower $\mathrm{Tf}^{\mathrm{d}} \mathbf{2}$ were not distinguished from one another, as in most descriptions to date, the compound allelomorphs $\mathrm{Tf} d$ appeared to be about as widespread as $\mathrm{Tf}^{\mathrm{a} 2}$ and more frequent in many breeds. This composite character $\mathrm{Tf}^{\mathrm{d}}$ has been reported to occur frequently in Brown Swiss cattle tested in California, and in three breeds which are known to be derived from the Simmental breed of West Switzerland. Their $\mathrm{Tf}^{\mathrm{d}}$ frequencies were 0.69 in Brown Swiss, 0.68 in Czechoslovak Red Spotted, 0.7I in Hungarian Red Spotted and 0.85 in the Spotted Mountain breed in southern Germany. The high $\mathrm{Tf}^{\mathrm{d}}$ frequencies extended to the other German highland breeds and to the Grey Steppe cattle. The absence 
of Tfd from I4 Sindhi cattle of Indian origin is the only breed example, small though it be, of the absence of both $\mathrm{Tf}^{1} 1$ and $\mathrm{Tf}^{\mathrm{d}} 2$.

As yet the subdivisions of Tf have not been reported from Scandinavia though both must be present among those Scandinavian cattle related to the Friesian and Ayrshire breeds. One dose of $\mathrm{Tf}^{\mathrm{d} 1}$ and five doses of $\mathrm{Tf}^{\mathrm{d} 2}$ were found in six Danish Red bulls imported into England. Outside Britain, $\operatorname{Tf}^{d}{ }^{1}$ and $\mathrm{Tf}^{\mathrm{d} 2}$ have both been recognised in the Valdostana and Piedmont cattle of Italy and by the author in the Hungarian Red Spotted breed.

$T f^{d 1}$. Kristjansson reported this gene in a few Friesian and Ayrshire cattle in an Ottawa experimental herd in 1962. This gene is present in most British breeds but absent from the British White and the Red Poll samples, and from eight Lincoln Red Shorthorn bulls. Although the gene $\operatorname{Tf}^{d 1}$ was not present in nine Galloway bulls at A.I. centres, it was found to have a frequency of $0 \cdot 16$ in a Galloway herd.

In many breeds, $\operatorname{Tf}^{d 1}$ was less frequent than $\operatorname{Tfd}^{2}$. If this had been universal, it would have been tempting to think of $\operatorname{Tf}^{\mathrm{d}} 1$ as an occasional variant of $\mathrm{Tf}^{2} 2$, but the frequency relationship was reversed in the Aberdeen Angus, South Devon and Sussex breeds, Tf ${ }^{1} 1$ being more frequent than $\mathrm{Tf}^{\mathrm{d} 2}$.

$T f^{d 2}$. Where this gene was recognised, it was found usually to be very common and it was present in all adequately tested herds. $\mathrm{Tf}^{\mathrm{d} 2}$ often accounted for a major part of the $\mathrm{Tf}^{\mathrm{d}}$ frequencies reported in earlier work. Examples of high $\mathrm{Tf}^{2}$ frequencies in Britain are $0.5^{8}$ in Longhorns, 0.53 in 19 Welsh Black, 0.47 in Devon, and 0.54 in the Charollais bulls imported to England from France. This gene was moderately well represented in all of the remaining British breeds except the Aberdeen Angus, in which it was uncommonly low at 0.04. Outside Britain few tests have been made for $\mathrm{Tf}^{\mathrm{d}} 2$, but the existing results suggest that the high frequencies of $T f d$ in the various national varieties of Simmental and Grey Steppe cattle probably are due largely to the gene $\mathrm{Tf}^{2} \mathbf{2}$ recently observed at high frequencies in the Aosta breed in Italy and in a sample of Hungarian cattle sera.

$T f^{f}$. This gene has not been found in British cattle nor reported in any European breed. All the existing examples of $\mathrm{Tf}^{f}$ were in zebu or in breeds believed to have a measure of zebu ancestry. It has appeared in all the nine breeds known to contain $\mathrm{Tf}^{\mathrm{b}}$, namely Sahiwal, Sindhi, Ankole, Boran, Nganda, Nguni, Tanganyika Shorthorned Zebu, Teso and East Turkish. It also appears in two Anatolian breeds not known to have $\mathrm{Tf}^{\mathrm{b}}$.

$T f^{e}$. The Chartley herd of British White in the Whipsnade gene bank had the highest frequency of this gene, but if the Dexter twins in table 6 are typical of their breed, a high Tfe frequency may be anticipated in the indigenous cattle of Ireland. The gene is relatively common at 0.39 in I 5 samples from a fold of Highland cattle, also in Galloway at 0.34 and in Red Poll at 0.27 . Because Tfe is more prominent in the Swedish Red-and-White breed, 0.29, than in its Ayrshire 
relatives, $\mathrm{O} \cdot 10$, presumably $\mathrm{Tf} \mathrm{e}^{\mathrm{o}}$ occurred frequently in its Swedish Red Pied lineage. Low Tfe frequencies were found in British Friesian $(0 \cdot 05)$, Belted Galloway (0.04), Dairy Shorthorn (0.02) and Hereford $(0.01)$, and Iceland cattle showed 0.01 .

The gene $\mathrm{Tfe}$ was absent from significantly sized samples of Charollais, Devon, Jersey, Guernsey, and South Devon, and from 19 Welsh Black and 9 Sussex bulls. This gene is also rare or absent in most of the breeds of Central Europe; Grey Steppe cattle from Rumania and Montafon cattle from Hungary had no Tfe. It is present but rare in the Brown Swiss of California. In Italy, this gene occurred occasionally in the Piedmont and Valdostana breeds.

Two samples of Sahiwal cattle from India showed moderate proportions of $\mathrm{Tf}$, and its frequency in the native Anatolian Black cattle of Turkey was $0 \cdot 40$. This gene is well represented in five East African breeds with different proportions of zebu ancestry and in South Africa in the Nguni $(0 \cdot 33)$, Afrikaner $(0 \cdot 27)$ and Drakensberger $(0 \cdot 20)$ breeds.

$T f^{g}$. This rare gene was found recently in South Africa where its frequency and distribution is now being investigated in Afrikaner and related varieties of cattle (Osterhoff, r 964).

Possible additional $T f$ genes. In most species, the number of recognisable transferrin types has increased due to more discriminating techniques and further exploration of varieties and breeds of animals not previously examined. This trend may be expected to continus. For example a rare transferrin pattern was suspected in the Chillingham Park herd of British White (Hall, pers. comm.).

\section{(v) Clines}

Some of the bovine $\mathrm{Tf}$ genes are common to many regions, but some of the Tf genes described in cattle of Asiatic origin are absent or very rare in Europe and in South Africa. A cline may extend from India via East Africa to South Africa, and another from India through part of Turkey does not reach Europe. The former suggested cline is represented by Sahiwal and Sindhi in India; Boran, Tanganyika Shorthorned Zebu and Teso in East Africa; Nganda are between East African Zebu and Sanga; Ankole and Ngnuni represent the Sanga cattle; Afrikaner are at one extremity. An increase in $\mathrm{Tf}^{\mathrm{a} \mathbf{2}}$ along this cline from Sahiwal to Afrikaner compensates for a decrease in $\mathrm{Tf}^{\mathrm{b}}$ and $\mathrm{Tf}^{\mathrm{f}}$, while $\mathrm{Tf}^{\mathrm{d}}$ frequencies increase erratically and $\mathrm{Tf}^{\mathrm{e}}$ remains almost uniform. The other suggested cline follows a similar transition. The genes $\mathrm{Tf}^{\mathrm{b}}$ and $\mathrm{Tf}^{\mathrm{t}}$, prominent in Indian cattle, are rarer in the East Turkish breed, two Anatolian breeds showed less $\mathrm{Tf}^{\mathrm{f}}$ and no $\mathrm{Tf}^{\mathrm{b}}$, and neither $\mathrm{Tf}^{\mathrm{a}}$ nor $\mathrm{Tf}^{\mathrm{b}}$ has been reported in European cattle.

The genes $\mathrm{Tf}^{\mathrm{a}}$, $\mathrm{Tf}^{\mathrm{d}}$ and $\mathrm{Tf}$ appear the same in Afrikaner and in most European breeds. This similarity was confirmed in tests on the Drakensberger and Bonsmara breeds, both containing Afrikaner and European cattle genes. The Afrikaner and Red Poll breeds have surprisingly similar $\mathrm{Tf}$ gene frequencies. This could be fortuitous. 


\section{(vi) Interactions and associations}

An absence of any pronounced interaction between environment and cattle transferrin is indicated by the general uniformity within each of the several breeds of cattle interspersed throughout Britain. Other evidence for this indifference to environment is found in the constancy of the frequencies in many dispersed branches of the breeds in tables 6 and 7. For example, the Dutch pied cattle showed similar gene frequencies in samples from the Netherlands, Germany, Denmark, Sweden, South Africa, America and Britain. Other breeds showed similar constancy. Aberdeen Angus, Ayrshire Shorthorn, Hereford, and Jersey breeds have been tested in America, South Africa, Canada and Australia; Jersey cattle in Denmark also; Red Poll, South Devon and Sussex in South Africa; Guernsey and Brown Swiss in America and South Africa; Longhorn in Texas, Norwegian cattle in Iceland, and Indian breeds in East Africa and Australia. Among the many examples of dispersion a few showed gene frequencies atypical of their breed. For example the Ayrshire sample in South African was atypical. Presumably such deviants resulted from local drifting of gene frequencies in the course of occasional breeding bottlenecks in herds. Some of the dispersed breed samples were in herds founded on few animals, some breeds have been replenished from their home territories, and some have experienced long periods of genetic isolation. An extreme example is the Iceland breed isolated for nine centuries and yet showing transferrin proportions similar to those in their modern Norwegian relatives (Braend, et al., 1962).

Other results gave no indication that any particular transferrin type was selected by a particular set of climatic conditions. For example $\mathrm{Tf}^{\mathrm{e}}$ is concentrated in cattle breeds found in India, Northern Sweden, Western Scotland, East Anglia and in cattle ornamenting a few English parks. As no common environmental factor appears responsible this distribution could be the chance survival of an ancient gene or the products of identical mutations in different regions.

The results did not suggest that artificial selection for any particular property had favoured the concentration of any transferrin gene in different breeds selected for any single purpose. Although it was claimed that cattle with $\mathrm{Tf}^{\mathrm{d}}$ genes produced more milk (Ashton 1960 ) there is no apparent concentration of $\mathrm{Tf}^{\mathrm{d}}$ genes in the dairy breeds. Some of the highest $\mathbf{T f}^{\mathrm{d}}$ frequencies are in certain breeds associated with central and south-eastern Europe, and this concentration of $T f^{d}$ appears to indicate the genetic affinities of those breeds rather than their capacity to produce milk.

The transferrin results may be discussed in relation to the findings at other genetic loci. The haemoglobin genes have been described in many of the breeds considered here, and the following examples consider haemoglobin types in relation to transferrin types. The first and second examples show how the observations at two genetic loci 
may suggest conflicting interpretations; the third example shows how the observations at two loci may fit one general interpretation applicable to both.

Example 1. Cattle haemoglobin A is the only haemoglobin present throughout the breeds associated with northern Europe, including all of the breeds north of an imaginary line through Devon and along the English Channel. Breeds with haemoglobin A and B are found south of this line in South Devon, Jersey, Guernsey, France, Switzerland, etc. The haemoglobin data suggest two communities of cattle breeds (Bangham I 957, Bangham and Blumberg I958) but there is no correspondingly abrupt change in the transferrin types of the breeds on either side of the line.

Example 2. The cattle haemoglobin B has two frequency peaks, one in Jersey in the English Channel and another in Kathiawar, India (Lehmann, 1959). Between those two places are many examples of breeds showing lower frequencies of haemoglobin $B$.

If this chain of breeds represents a migration route (Boston, 1954), some other genetic similarities may follow the same course but the transferrin genes $\mathrm{Tf}^{\mathrm{b}}$ and $\mathrm{Tf}^{\mathrm{f}}$, common in India, do not appear in Europe. In the absence of corroboration from other genetic loci the two peaks of bovine haemoglobin $B$ could be due to the occurrence of the same mutation in two places and its spread in two genetically different populations.

Example 3. The transferrin genes $\operatorname{Tf}^{\mathrm{b}}$ and $\operatorname{Tf}^{\mathrm{f}}$ and the haemoglobin gene $\mathrm{Hb}^{\mathbf{B}}$ appear together in Indian cattle, and in cattle which have spread into Africa from India. The occurrences of $\mathrm{Tf}^{\mathrm{b}}, \mathrm{Tf}^{\mathrm{f}}$ and $\mathrm{Hb}^{\mathrm{B}}$ all decrease in frequency from India, through East Africa on towards South Africa.

Other examples, similar to the above, may be drawn from the data presented here, but in the absence of more extensive data involving several genetic loci, the interpretations are premature.

\section{DISCUSSION}

Transferrin polymorphism is the common state in cattle and was presumably present in their feral ancestors. This variation is attributed to sets of three or more allelomorphic genes in each breed of cattle. It is most improbable that this widespread variation could be maintained by recurrent mutations alone. There is no report of a particular transferrin mutation happening. Quantitative genetic changes in cattle transferrins are implied by the existence of a series of at least eight known allelomorphic genes at the cattle Tf locus. The zebu has at least two allelomorphs which are absent from the cattle of Europe, although both of those forms were derived by domestication of the extinct auroch, Bos primigenius Bojanus (Zeuner and Mourant, 1963). There are similar examples of allelomorphs being absent from groups of breeds in particular regions and from some herds within breeds. 
Herdsmen and breeders have assisted in the movements, hybridisation and enclosure of cattle. The cattle transferrin variation has survived the dispersal of the domestic cattle accompanying the human migrations and the trade routes. This variation also survives within the boundaries of all breeds. The extent of the genetic variation observed in the many populations already studied may be interpreted as a commentary on their formation, their degrees of genetic isolation and the random effects of particular breeding systems.

The successful breeding unit appears to be the herd with a number of complementary types, and the statistical description of the cattle transferrin types in breeds and herds should be considered against a natural background in which some balancing mechanism maintains the polymorphism. Some statistical accounts have shown curiously inconsistent differences of fertility, embryonic survival and fitness (Ashton, I961; Ashton and Fallon, 1962; Rausch, et al., I963) but detailed family studies show no disproportionate segregation (Jamieson, 1965) and the extensive data in the present paper do not show an excess of heterozygotes. Indeed the numbers of heterozygotes were occasionally deficient, but this was attributed to the composition of those samples. However, the possibility of a survival advantage favouring heterozygotes cannot be dismissed (Osterhoff, I964).

The known factors which interact to bring about genetic variation are mutation, migration, selection and drift. The present study offers no information on the incidence of mutation. The cattle which are genetically isolated in breeds at home and abroad often provide examples of isolates existing side by side in each of several environments, but each breed maintains its individuality, as indicated by its transferrins, regardless of the environmental differences. The genotypes of some breeds may offer indirect information about the regional varieties from which they were formed. The remaining factors, selection and genetic drift, presumably influenced the transferrin types. It is probable that both factors operate, but as yet there is no means of allocating their relative importance. If most of the genetic differences between breeds were established during the collection of foundation animals and their subsequent early multiplication, the influence of genetic drift would almost inevitably have created some monomorphic populations but those have not appeared in the 63 breeds tested to date.

There is no convincing evidence that any particular transferrin type is better than any other, but it is difficult to regard the cattle Tf genes as completely neutral. The transferrin diversity could be due to some heterozygous types being favoured by unknown factors, or the distinct proportions of transferrin types characteristic of particular breeds may suggest that other genetic factors within the breeds themselves may influence the characteristic equilibrium points of their transferrins.

The results of tests for transferrins were not available in the past 
and no deliberate effort has yet been made to use a transferrin gene in any definition of a breed or variety. Unlike coat colours, horns, shapes, and sizes which have been the subject of artistic or practical fashions, the transferrins provide an objective description of the genetic variation which continues regardless of any imposed breeding restriction. In the future, one could test for transferrins in the descendants of our present cattle to look for genetic changes brought about by the current trends towards specialisation and uniformity, or by the occurrence and subsequent spread of mutations or imported genes.

Detailed information based on several independent genetic loci is required before a historical interpretation of the cattle breeds can be stated confidently. The transferrin data reveals the genes at one locus only. The correct interpretation of this scant information must be corroborated after testing for other genes at independent loci. Other genetic systems are recognised on about half of the bovine chromosomes but, apart from the transferrins and the haemoglobins, too few loci have been considered systematically in the British cattle breeds. As the haemoglobin and transferrin types describe two independent parts of the genotype the interpretations of their distributions should complement each other. When the different animal blood group systems allow the description of genes at several independent genetic loci, populations may be characterised in great detail. Such data may be used in several ways other than in parentage tests. For example, the reappraisal of breed histories and of herd book analyses may be attempted using known genetic markers. The genetic consequences of domestication may become more apparent if similar marker genes are used to supplement the existing taxonomic information about related varieties, and in the broader sense the same approach using natural forms should promote the study of the evolution and ecology of genes.

\section{CONCLUSIONS}

I. Cattle transferrin polymorphism was found in each adequately tested herd.

2. Hardy-Weinberg equilibrium was found at the cattle transferrin locus in random mating populations, but not in some breed samples containing bulls born in several partly isolated herds high in the hierarchies of their breeds.

3. The genetic drifting suspected in some herds, and the more persistent breed differences, suggest that chance assortments of the transferrins in the foundation stocks of some breeds prejudiced the gene frequencies in their descendants.

4. When all the breeds of pedigree cattle are arranged in their original territories, they still suggest a few distinct communities of transferrin types among the geographic varieties which preceded the breeds.

5. The transferrins observed in domestic cattle do not suggest any "wild type" cattle transferrin. 
6. In the indigenous varieties of cattle some transferrin allelomorphs are world-wide, at least two allelomorphs are confined to zebu, most of the known genes are spread over large regions and their frequencies show peaks, clines and discontinuities.

7. The transferrin gene frequencies which characterise each breed remain about constant in samples of the same breed dispersed in different countries and continents.

8. All of the possible interpretations of the distribution of cattle transferrins should be corroborated using the recognisable genes on the remaining chromosomes.

Acknowledgments. - I am pleased to acknowledge material provided by Dr G. C. Ashton, Dr H. Boyd, Mr A. L. Ogden, Dr I. W. Rowlands, Dr J. A. A. Watt, Mr G. F. Smith and the veterinary officers of the Milk Marketing Board. I am indebted to the owners and managers of the herds from which samples were taken.

\section{REFERENCES}

Astron, G. C. 1958. Genetics of Beta-globulin polymorphism in British cattle. Nature (Lond.), ${ }_{182}, 370-372$.

Ashron, G. C. 1959. Beta-globulin alleles in some Zebu cattle. Nature (Lond.), $184, \mathrm{I} 135-6$.

Ashton, G. c. I96o. Beta-globulin polymorphism and economic factors in dairy cattle. 7. Agric. Sci., 54, 32 1-328.

Ashton, G. C. 1961. Beta-globulin type and fertility in artificially bred dairy cattle. 7. Reprod. Fert., 2, I1 7-129.

AShton, G. C., AND Fallon, G. R. 1962. Beta-globulin type, fertility and embryonic mortality in cattle. 7. Reprod. Fert., 3, 93-104.

ASHTON, G. C., AND LAMPKIN, G. H. I965a. Serum albumin and transferrin polymorphism in East African cattle. Nature (Lond.), 205, 209-210.

AShton, G. C., AND LAMPKin, G. H. 1965b. Transferrin and post-albumin polymorphism in East African cattle. Genet. Res. Camb., 6, 209-21 5 .

BANGHAM, A. D. 1957. Distribution of electrophoretically different haemoglobins among cattle breeds of Great Britain. Nature (Lond.), 179, 467-8.

BANGHAM, A. D., AND BLUMBERG, B. s. 1958. Distribution of electrophoretically different haemoglobins among some cattle breeds of Europe and Africa. Nature (Lond.), $181,155^{1-1} 55^{2}$.

Boston, E. G. 1954. Jersey cattle. Faber and Faber, London.

BRAEND, M., RENDEL, J., GAHNE, B., AND ADALSTEINSSON, S., 1962. Blood groups in Icelandic cattle. Hereditas, 48, 264-283.

BRUMmerstedt-HANSEN, E., MOUSTGAARd, J., ANd Møller, IL. 1962. Serumtypestemmelse inden for danske kvaegracer 1959-62. Den kongelize Veterinaerog Landbohøjskole Institut for Sterilitetsforskning, Aarsberlting.

Buchanan-Smith, A. D. 1937. The Ayrshire breed past, present, future. Trans. Highl. agric. Soc. Scot., 79, 73-1 10.

buschmanN, H. 1963. Die Bedeutung der Serumtypenbestimmung für die forensische Veterinärmedizin. Zeutbl. Vetmed., B ro, 49-56.

BuschmanN, H., AND SCHMID, D. o. I964. Untersuchunger über den genetischen Serumtransferrin und Hämoglobin polymorphismus deutscher Rinderrassen Zeutbl. Vetmed., A ${ }_{11}, 235$.

Datra, s. P., AND stone, w. H. 1963. Transferrins in cattle twins. Proc. Soc. Exp. Biol. Med. N.Y., It3, 756-759.

GAHNE, во. 1961. Studies of transferrins in serum and milk of Swedish cattle. Anim. Prod., 3, 135-145. 
GALL, G. A. E., AND BERG, R. T. 1964. Studies of the inheritance of bovine serum transferrins. Anim. Prod., 6, 107-118.

Jamieson, A. 1965. The genetics of transferrins in cattle. Heredity (Lond.), 20, 419-441.

KRISTJANSSON, F. K. 1962. Recent research in serum protein polymorphisms. 8th Animal blood group conference in Europe. Ljubljana.

LehmanN, H. 1959. The haemoglobins of 103 Gir cattle. Man, 1959, 91 .

LUSH, J. L. 1946. Chance as a cause of changes in gene frequency within breeds of livestock. Am. Nat., 8o, 318-342.

MASON, 1. L. 1957. A world dictionary of breeds, types and varieties of livestock, with supplement. Commonwealth Agricultural Bureaux, Farnham House, Slough, Bucks., England.

MATHER, K. I951. Statistical analysis in biology. Methuen \& Co. Ltd., London. MÁRKUS, J., KoVÁcs, GY., AND FEsüs, L. 1964. The frequency of genes controlling serum Beta-globulin in Hungarian spotted cattle. Acta vet. hung., 14, 437-442.

ogden, A. L. 1963. Cattle Beta-globulins, Man and Cattle. Proceeding of a symposium on domestication. Royal Anthropological Institute. Occasional paper 18, I56-I 57. London.

OSTERHOFF, D. R. 1964. Recent research on biochemical polymorphism in livestock J. S. Afr. vet. med. Ass., 35, 363-380.

RAUSGH, W. H., LUDWICK, T. M., WESELI, D. F., RIGHARDSON, D. O., RADER, E. R., BRUM, E. W., hines, H. C., FoWler, A. K., AND Plowman, D. 1963. Association of bovine transferrin types as determined by disc electrophoresis, with fertility and production. Dairy Sci., 46, 648 .

SALERNO, A. 1964. Ricerche electrophoretiche su alcuni sistemi biochimici polimorfi nei bovini. Studio genetico della transferrine nella razza Romagnola. Prod. anim. (Napoli), 3, I -8.

SARTORE, G., DASSAT, P., AND BERNoco, D. 1963. Analisi dei bovini valdostani per emoglobine e transferrine. Atti Soc. ital. Sci. vet., 17. Suppl to Arch vet ital., 15, 222.

SCHROFFEL, J., AND MATOUSEK, J. 1962. Beta-globuling sera cervenostrakatych byků Sb. csl. Akad. semed Ved. E (XXXV), 5, 313-318.

SMITHIES, O., AND HICKMAN, G. G. 1958. Inherited variations in the serum proteins of cattle. Genetics, 43, 374.

STONAKER, H. H. 1943. The breeding structure of the Aberdeen Angus breed. 7 . Hered., 34, 322-328.

TROW-SMITH, R. 1959. A history of British livestock husbandry to 1700 , and 1700 to 1900. (2 vols.) Routledge and Kegan Paul, London.

wahlund, s. 1928. Zusammensetzung von Populationen und Korrelationserschinungen von Standpunkt der Vererbungslehre aus betrachtet. Hereditas, II, 65-108.

zEUNER, F. E., AND mourant, A. E. 1963. Summary of the symposium, Man and Cattle. Royal Anthropological Institute. Occasional paper 18, $158-166$. London. 